\title{
LEVEL II SCOUR ANALYSIS FOR BRIDGE 19 (CHARTH00390019) on TOWN HIGHWAY 39, crossing MAD BROOK, CHARLESTON, VERMONT
}

U.S. Geological Survey Open-File Report 97-212

Prepared in cooperation with

VERMONT AGENCY OF TRANSPORTATION and

FEDERAL HIGHWAY ADMINISTRATION 


\section{LEVEL II SCOUR ANALYSIS FOR BRIDGE 19 (CHARTH00390019) on TOWN HIGHWAY 39, crossing MAD BROOK, CHARLESTON, VERMONT}

By Erick M. Boehmler and Robert E. Hammond

U.S. Geological Survey Open-File Report 97-212

Prepared in cooperation with

VERMONT AGENCY OF TRANSPORTATION

and

FEDERAL HIGHWAY ADMINISTRATION 


\title{
U.S. DEPARTMENT OF THE INTERIOR BRUCE BABBITT, Secretary
}

\author{
U.S. GEOLOGICAL SURVEY \\ Gordon P. Eaton, Director
}

For additional information write to:

District Chief

U.S. Geological Survey 361 Commerce Way

Pembroke, NH 03275-3718
Copies of this report may be purchased from:

U.S. Geological Survey

Branch of Information Services

Open-File Reports Unit

Box 25286

Denver, CO 80225-0286 


\section{CONTENTS}

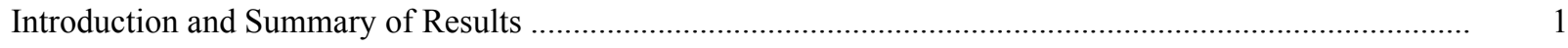

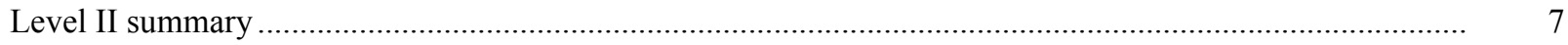

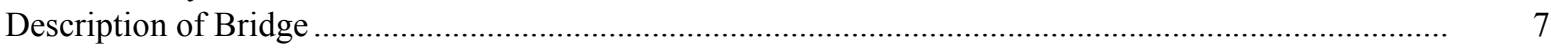

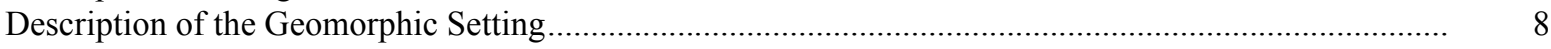

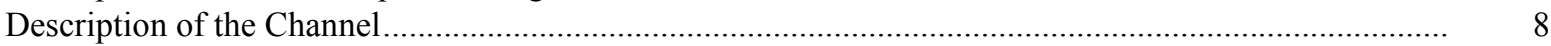

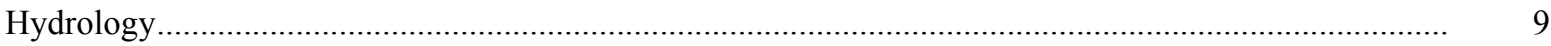

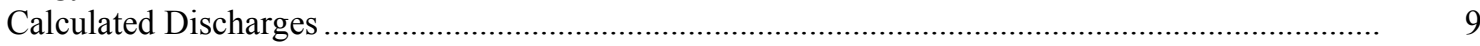

Description of the Water-Surface Profile Model (WSPRO) Analysis ......................................................... 10

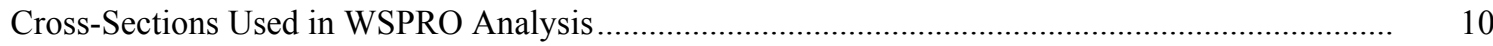

Data and Assumptions Used in WSPRO Model ...........................................................................

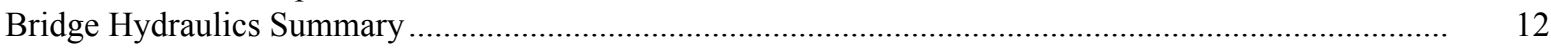

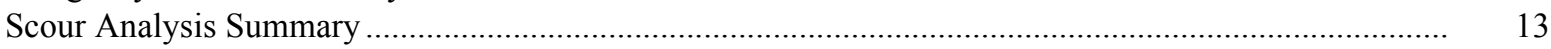

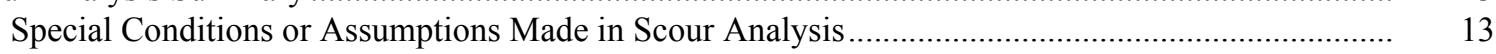

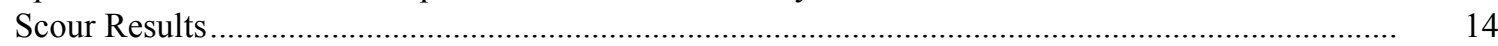

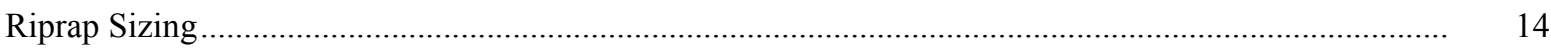

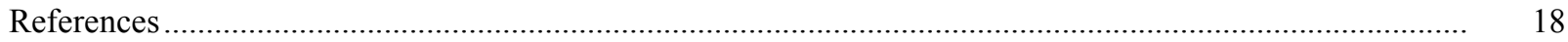

Appendixes:

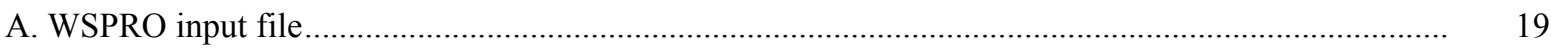

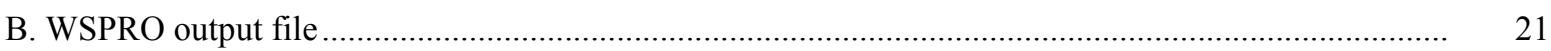

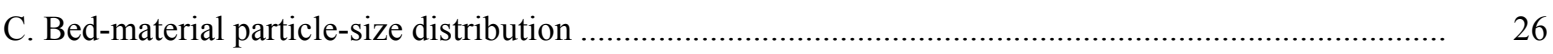

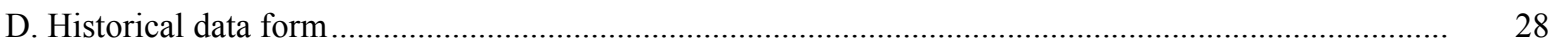

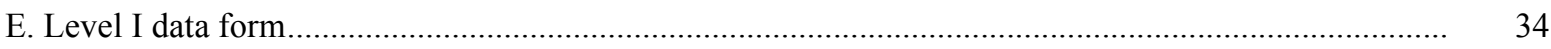

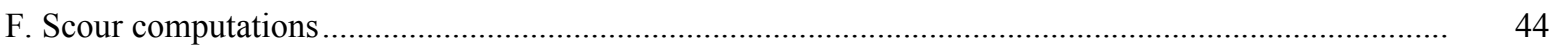

\section{FIGURES}

1. Map showing location of study area on USGS 1:24,000 scale map ........................................................

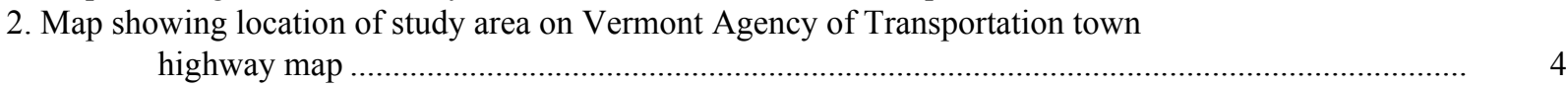

3. Structure CHARTH00390019 viewed from upstream (October 26, 1994) ……........................................ 5

4. Downstream channel viewed from structure CHARTH00390019 (October 26, 1994)............................ 5

5. Upstream channel viewed from structure CHARTH00390019 (October 26, 1994).................................... 6

6. Structure CHARTH00390019 viewed from downstream (October 26, 1994). .......................................... 6

7. Water-surface profiles for the 100- and 500-year discharges at structure

CHARTH00390019 on Town Highway 39, crossing Mad Brook,

Charleston, Vermont.

8. Scour elevations for the 100- and 500-year discharges at structure

CHARTH00390019 on Town Highway 39, crossing Mad Brook,

Charleston, Vermont.

\section{TABLES}

1. Remaining footing/pile depth at abutments for the 100-year discharge at structure

CHARTH00390019 on Town Highway 39, crossing Mad Brook,

Charleston, Vermont

2. Remaining footing/pile depth at abutments for the 500-year discharge at structure

CHARTH00390019 on Town Highway 39, crossing Mad Brook,

Charleston, Vermont. 


\begin{tabular}{|c|c|c|}
\hline Multiply & By & To obtain \\
\hline \multicolumn{3}{|c|}{ Length } \\
\hline inch (in.) & 25.4 & millimeter (mm) \\
\hline foot (ft) & 0.3048 & meter (m) \\
\hline mile (mi) & 1.609 & kilometer (km) \\
\hline \multicolumn{3}{|c|}{ Slope } \\
\hline foot per mile (ft/mi) & 0.1894 & meter per kilometer $(\mathrm{m} / \mathrm{km})$ \\
\hline \multicolumn{3}{|c|}{ Area } \\
\hline square mile $\left(\mathrm{mi}^{2}\right)$ & 2.590 & square kilometer $\left(\mathrm{km}^{2}\right)$ \\
\hline \multicolumn{3}{|c|}{ Volume } \\
\hline cubic foot $\left(\mathrm{ft}^{3}\right)$ & 0.02832 & cubic meter $\left(\mathrm{m}^{3}\right)$ \\
\hline \multicolumn{3}{|c|}{ Velocity and Flow } \\
\hline foot per second (ft/s) & 0.3048 & meter per second $(\mathrm{m} / \mathrm{s})$ \\
\hline cubic foot per second $\left(\mathrm{ft}^{3} / \mathrm{s}\right)$ & 0.02832 & cubic meter per second $\left(\mathrm{m}^{3} / \mathrm{s}\right)$ \\
\hline cubic foot per second per & 0.01093 & cubic meter per \\
\hline square mile & & second per square \\
\hline$\left[\left(\mathrm{ft}^{3} / \mathrm{s}\right) / \mathrm{mi}^{2}\right]$ & & kilometer $\left[\left(\mathrm{m}^{3} / \mathrm{s}\right) / \mathrm{km}^{2}\right]$ \\
\hline
\end{tabular}

\section{OTHER ABBREVIATIONS}

$\begin{array}{lrlr}\text { BF } & \text { bank full } & \text { LWW } & \text { left wingwall } \\ \mathrm{cfs} & \text { cubic feet per second } & \mathrm{MC} & \text { main channel } \\ \mathrm{D}_{50} & \text { median diameter of bed material } & \text { RAB } & \text { right abutment } \\ \mathrm{DS} & \text { downstream } & \text { RABUT } & \text { face of right abutment } \\ \text { elev. } & \text { elevation } & \text { RB } & \text { right bank } \\ \mathrm{f} / \mathrm{p} & \text { flood plain } & \text { ROB } & \text { right overbank } \\ \mathrm{ft}^{2} & \text { square feet } & \text { RWW } & \text { right wingwall } \\ \mathrm{ft} / \mathrm{ft} & \text { feet per foot } & \text { TH } & \text { town highway } \\ \mathrm{JCT} & \text { junction } & \text { UB } & \text { under bridge } \\ \text { LAB } & \text { left abutment } & \text { US } & \text { upstream } \\ \text { LABUT } & \text { face of left abutment } & \text { USGS } & \text { United States Geological Survey } \\ \text { LB } & \text { left bank } & \text { VTAOT } & \text { Vermont Agency of Transportation } \\ \text { LOB } & \text { left overbank } & \text { WSPRO } & \text { water-surface profile model }\end{array}$

In this report, the words "right" and "left" refer to directions that would be reported by an observer facing downstream.

Sea level: In this report, "sea level" refers to the National Geodetic Vertical Datum of 1929-- a geodetic datum derived from a general adjustment of the first-order level nets of the United States and Canada, formerly called Sea Level Datum of 1929.

In the appendices, the above abbreviations may be combined. For example, USLB would represent upstream left bank. 


\title{
LEVEL II SCOUR ANALYSIS FOR BRIDGE 19 (CHARTH00390019) ON TOWN HIGHWAY 39, CROSSING MAD BROOK, CHARLESTON, VERMONT
}

\author{
By Erick M. Boehmler and Robert E. Hammond
}

\section{INTRODUCTION AND SUMMARY OF RESULTS}

This report provides the results of a detailed Level II analysis of scour potential at structure CHARTH00390019 on Town Highway 39 crossing Mad Brook, Charleston, Vermont (figures 1-8). A Level II study is a basic engineering analysis of the site, including a quantitative analysis of stream stability and scour (U.S. Department of Transportation, 1993). Results of a Level I investigation also are included in this report in Appendix E. A Level I study provides a qualitative geomorphic characterization of the study site. Information on the bridge, gleaned from Vermont Agency of Transportation (VTAOT) files, was compiled prior to conducting Level I and Level II analyses and is found in Appendix D.

The site is in the White Mountain section of the New England physiographic province in northeastern Vermont in the town of Charleston. The 6.54- $\mathrm{mi}^{2}$ drainage area is in a predominantly rural and forested basin. In the vicinity of the study site, the surface cover is forest except for the upstream left side which is covered primarily with shrubs and brush. The immediate banks have dense woody vegetation.

In the study area, Mad Brook has an incised, sinuous channel with a slope of approximately $0.023 \mathrm{ft} / \mathrm{ft}$, an average channel top width of $40 \mathrm{ft}$ and an average channel depth of $4 \mathrm{ft}$. The predominant channel bed material is cobble with a median grain size $\left(\mathrm{D}_{50}\right)$ of $135.0 \mathrm{~mm}$ $(0.443 \mathrm{ft})$. The geomorphic assessment on October 26, 1994 indicated that the reach was laterally unstable due to long-term lateral migration of the channel. Data collection for the level II analysis was accomplished on October 26, 1994 and July 24, 1995.

The Town Highway 39 crossing of Mad Brook is a 34-ft-long, two-lane bridge consisting of one 31-foot steel-beam span (Vermont Agency of Transportation, written communication, August 4, 1994). The bridge is supported by vertical, concrete abutments with wingwalls. The channel is skewed approximately 40 degrees to the opening while the opening-skew-toroadway is 45 degrees.

A scour hole $1.5 \mathrm{ft}$ deeper than the mean thalweg depth was observed along the right abutment during the Level I assessment. The scour protection measures evident at the site were type-2 stone fill (less than 36 inches diameter) on the upstream left wingwall and upstream end of the left abutment wall. Type-3 stone fill (less than 48 inches diameter) was 
noted on the upstream right wingwall and the upstream side of the left road approach embankment. Additional details describing conditions at the site are included in the Level II Summary and Appendices D and E.

Scour depths and rock rip-rap sizes were computed using the general guidelines described in Hydraulic Engineering Circular 18 (Richardson and others, 1995). Total scour at a highway crossing is comprised of three components: 1) long-term streambed degradation; 2) contraction scour (due to accelerated flow caused by a reduction in flow area at a bridge) and; 3) local scour (caused by accelerated flow around piers and abutments). Total scour is the sum of the three components. Equations are available to compute depths for contraction and local scour and a summary of the results of these computations follows.

Contraction scour for all modelled flows was $0.0 \mathrm{ft}$. Abutment scour ranged from 9.5 to $16.7 \mathrm{ft}$. The worst-case abutment scour occurred at the 500-year discharge. Additional information on scour depths and depths to armoring are included in the section titled "Scour Results". Scoured-streambed elevations, based on the calculated scour depths, are presented in tables 1 and 2. A cross-section of the scour computed at the bridge is presented in figure 8. Scour depths were calculated assuming an infinite depth of erosive material and a homogeneous particle-size distribution.

It is generally accepted that the Froehlich equation (abutment scour) gives "excessively conservative estimates of scour depths" (Richardson and others, 1995, p. 47). Usually, computed scour depths are evaluated in combination with other information including (but not limited to) historical performance during flood events, the geomorphic stability assessment, existing scour protection measures, and the results of the hydraulic analyses. Therefore, scour depths adopted by VTAOT may differ from the computed values documented herein. 


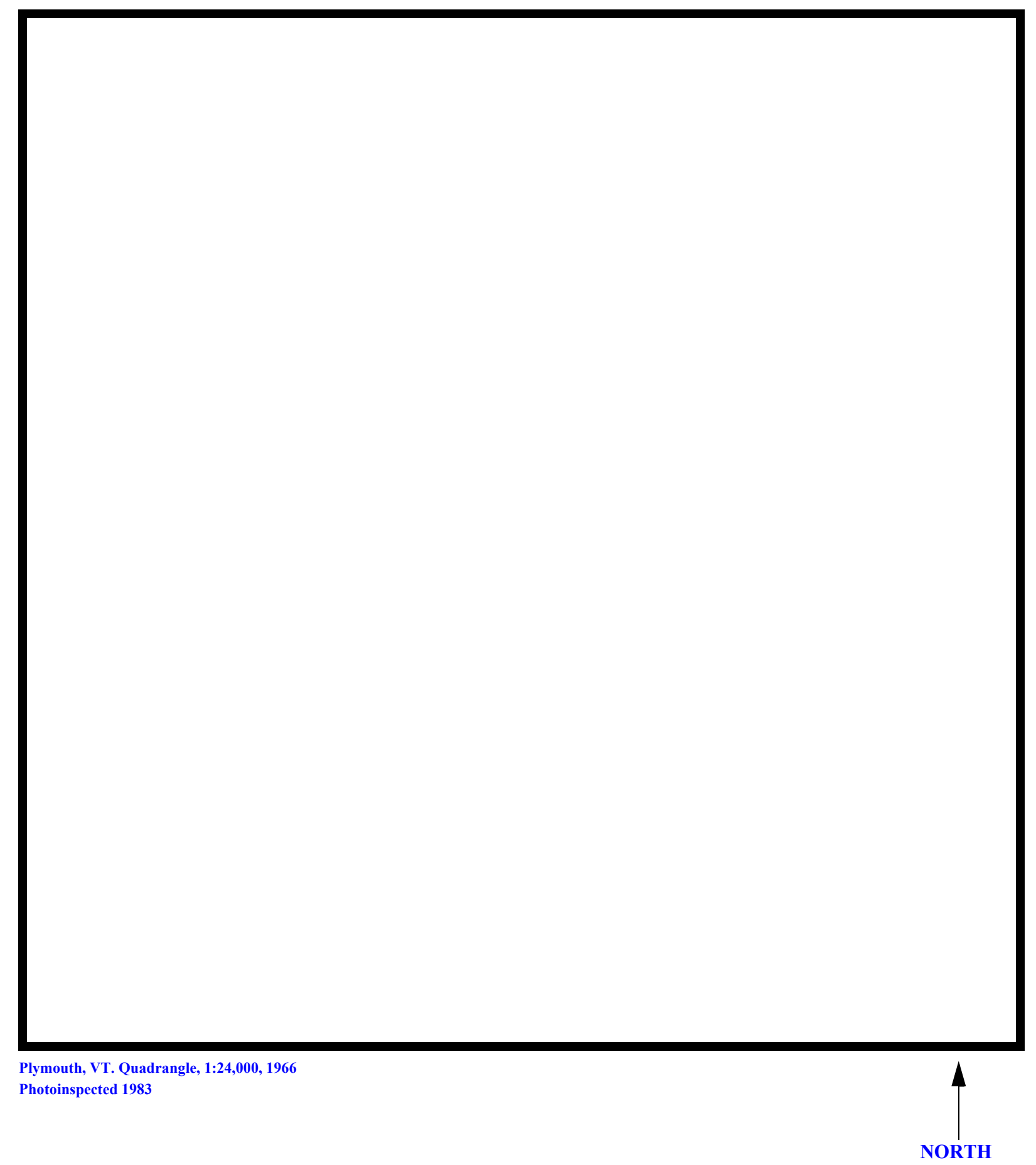

Figure 1. Location of study area on USGS 1:24,000 scale map. 
Figure 2. Location of study area on Vermont Agency of Transportation town highway map. 

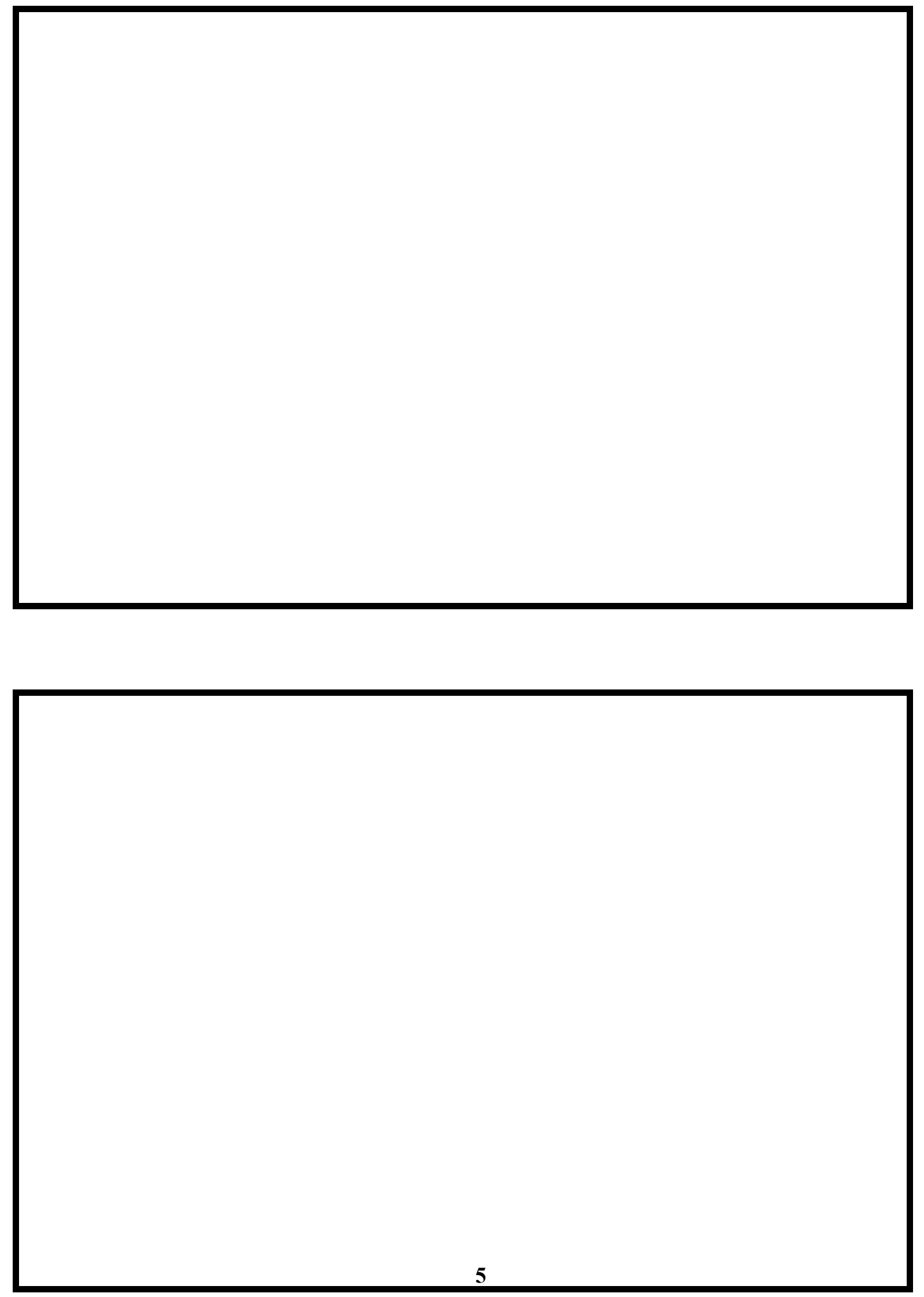

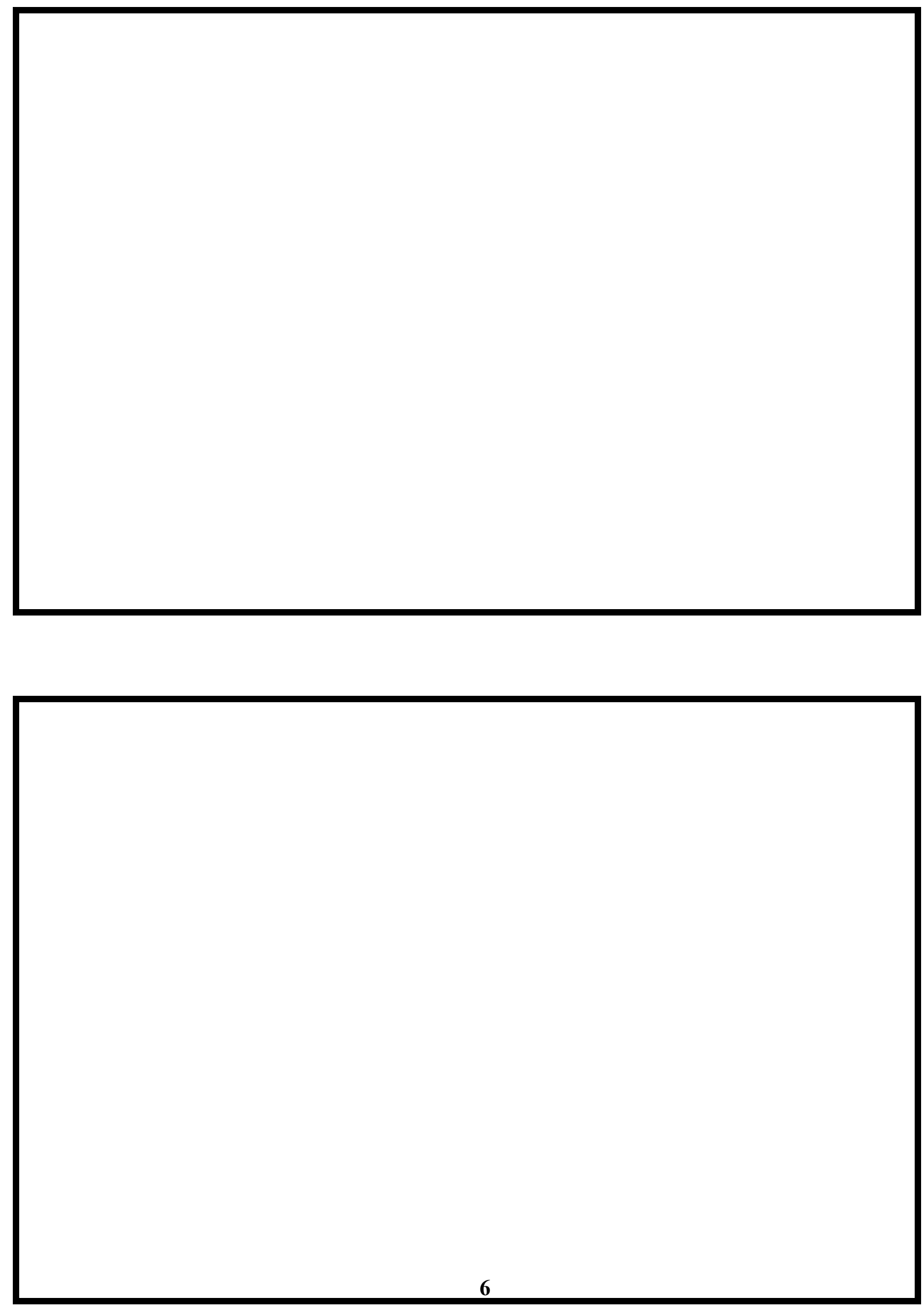


\section{LEVEL II SUMMARY}

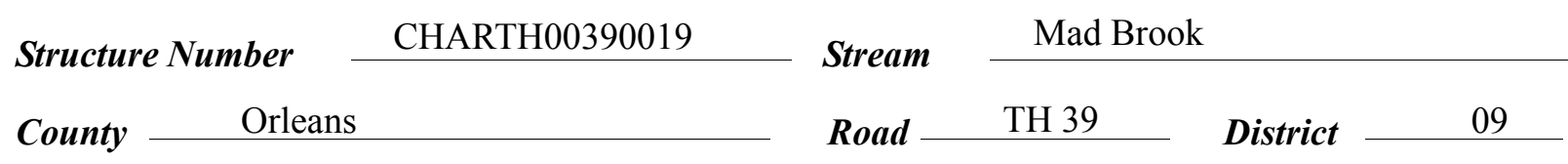

\section{Description of Bridge}

Bridge length $\quad 34 \quad f t$ Bridge width $\frac{24.4}{\text { Curve }} \quad$ Max span length $\stackrel{31}{f t}$

Alignment of bridge to road (on curve or straight)

Abutment type Vertical concrete

Stone fill on abutment?

$$
\text { No }
$$

\section{Embankment type}

nato of incnortion
Sloping

$10 / 26 / 94$

Dananimsin af atama fill Type-2 on the US end of the left abutment, and the US left wingwall. Type-3 on the US right wingwall and the upstream left road approach embankment. The right abutment is not protected.

Abutments and wingwalls are concrete. There is a $1.5 \mathrm{ft}$ deep scour hole in front of the right abutment.

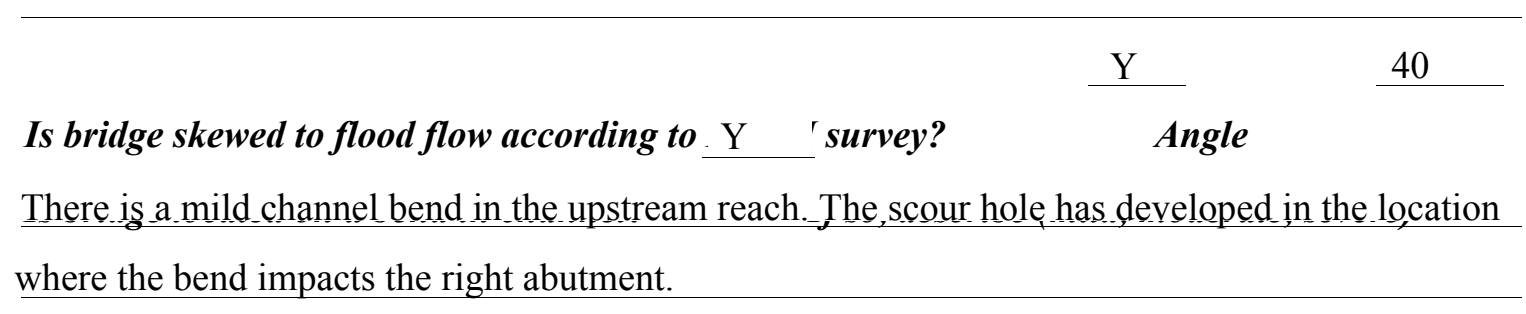

Debris accumulation on bridge at time of Level I or Level II site visit:

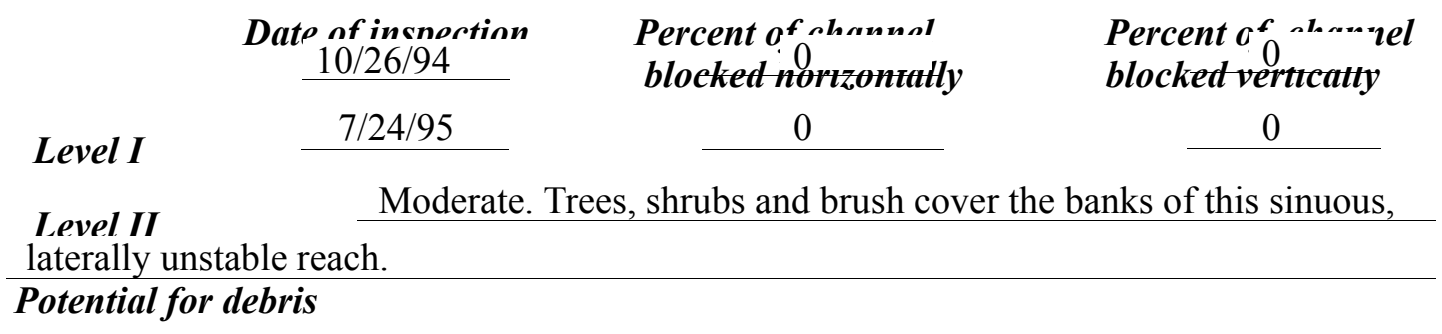

The left abutment has a two-tiered subfooting and the right abutment has a three-tiered Doscriho anv, foaturos noar ar at tho hridoo that mavy affort flou, (includo ahsorvation dato) subfooting noted on 10/26/94. Combined, the subfootings constrict the lower $1 / 4$ of the bridge opening up to 8 feet. $11 / 08 / 94$. 


\section{Description of the Geomorphic Setting}

General topography The channel is located within a narrow, moderate relief valley setting with little to no flood plains and steep valley walls on both sides.

Geomorphic conditions at bridge site: downstream (DS), upstream (US)

Date of inspection $\quad 10 / 26 / 94$

DS left: $\quad$ Steep channel bank to a narrow overbank area.

DS right: $\quad$ Steep channel bank to a narrow overbank area.

US left: $\quad$ Steep channel bank to TH 39 roadway embankment and surface.

US right: $\quad$ Steep channel bank to a narrow overbank area.

\section{Description of the Channel}

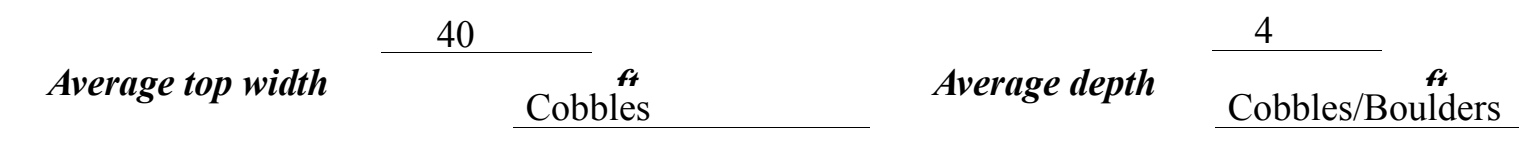

Predominant bed material

Bank material

Steep and sinuous

with semi-alluvial to non-alluvial channel boundaries and little to no flood plain.

$10 / 26 / 94$

Vegetative ${ }^{1}{ }_{1}$ Trees

DS left: $\quad$ Trees

DS right: $\quad$ Shrubs and brush with a few trees.

US left: $\quad$ Tress.

US right:

$\mathrm{N}$

Do banks appear stable? On 10/26/94 therewere cut-banks noted on the right bank upstream

and the left bank downstream with heavy tree root exposure and slumping bank material, which
date of observatton. indicate long-term channel migration.

Noted on $10 / 26 / 94$, the

left abutment wall and footings were formed around a 2 by 1 by 1 meter size boulder, which Describe any obstructions in channel and date of observation.

projects into the channel. The footings and subfootings also block and constrict flow through the lower $1 / 4$ of the bridge opening. 


\section{Hydrology}

Drainage area $\quad$ $\quad \mathrm{mi}^{2}$

Percentage of drainage area in physiographic provinces: (approximate)

Physiographic province/section

New England/ White Mountain
Percent of drainage area 100

Is drainage area considered rural or urban? Rural $\quad$ Describe any significant

urbanization: None.

Is there a USGS gage on the stream of interest?

No

\section{USGS gage description}

USGS gage number

Gage drainage area

$m i^{2}$

No

Is there a lake'.

\section{Calculated Discharges $\quad 1,780$ Q100 $\quad \mathrm{ft}^{3} / \mathrm{s}$}

The 100- and 500-year discharges were based on a

range determined from several empirical relationships (Benson, 1962; FHWA, 1983; Johnson and Tasker, 1974; Johnson and Laraway, unpublished draft, 1971; Potter, 1957; and Talbot, 1887). The values from the FHWA method were selected for this site due to the central tendency of the relationship with the others. 


\section{Description of the Water-Surface Profile Model (WSPRO) Analysis}

Datum for WSPRO analysis (USGS survey, sea level, VTAOT plans)

USGS survey

Datum tie between USGS survey and VTAOT plans

None

Description of reference marks used to determine USGS datum. $\quad$ RM1 is the center point

of a chiseled "X" on top of the DS end of the DS left wingwall (elev. $497.43 \mathrm{ft}$, arbitrary survey

datum). RM2 is the center point of a chiseled " $\mathrm{X}$ " on top of the US end of the US left wingwall

(elev. $496.38 \mathrm{ft}$, arbitrary survey datum).

\section{Cross-Sections Used in WSPRO Analysis}

\begin{tabular}{cccl}
\hline${ }^{1}$ Cross-section & $\begin{array}{c}\text { Section } \\
\text { Reference } \\
\text { Distance } \\
(\text { SRD) } \text { in feet }\end{array}$ & $\begin{array}{c}{ }^{2} \text { Cross-section } \\
\text { development }\end{array}$ & \multicolumn{1}{c}{ Comments } \\
\hline EXITX & -40 & 1 & Exit section \\
FULLV & 0 & 2 & $\begin{array}{l}\text { Downstream Full-valley } \\
\text { section (Templated from } \\
\text { EXITX) }\end{array}$ \\
BRIDG & 0 & 1 & $\begin{array}{l}\text { Bridge section } \\
\text { Modelled Approach sec- } \\
\text { APPRO }\end{array}$ \\
& 60 & 2 & $\begin{array}{l}\text { tion (Templated from } \\
\text { APTEM) } \\
\text { Approach section as sur- } \\
\text { APTEM }\end{array}$ \\
& 69 & 1 & $\begin{array}{l}\text { veyed (Used as a tem- } \\
\text { plate) }\end{array}$ \\
\hline
\end{tabular}

${ }^{1}$ For location of cross-sections see plan-view sketch included with Level I field form, Appendix E.

For more detail on how cross-sections were developed see WSPRO input file. 


\section{Data and Assumptions Used in WSPRO Model}

Hydraulic analyses of the reach were done by use of the Federal Highway Administration's step-backwater computer program, WSPRO (Shearman and others, 1986, and Shearman, 1990). The analyses reported herein reflect conditions existing at the site at the time of the study. Furthermore, in the development of the model it was necessary to assume no accumulation of debris or ice at the site. Results of the hydraulic model are presented in the Bridge Hydraulic Summary, Appendix B, and figure 7.

Channel roughness factors (Manning's " $n$ ") used in the hydraulic model were estimated using field inspections at each cross section following the general guidelines described by Arcement and Schneider (1989). Final adjustments to the values were made during the modelling of the reach. Channel " $\mathrm{n}$ " values for the reach ranged from 0.050 to 0.060 , and overbank " $n$ " values ranged from 0.030 to 0.095 .

Normal depth at the exit section (EXITX) was assumed as the starting water surface. This depth was computed by use of the slope-conveyance method outlined in the user's manual for WSPRO (Shearman, 1990). The slope used was $0.023 \mathrm{ft} / \mathrm{ft}$ which was estimated from surveyed thalweg points in the channel reach downstream of the site.

The surveyed approach section (APTEM) was moved along the approach channel slope $(0.0361 \mathrm{ft} / \mathrm{ft})$ to establish the modelled approach section (APPRO), one bridge length upstream of the upstream face as recommended by Shearman and others (1986). This location also provides a consistent method for determining scour variables.

The 100- and 500-year discharge models indicate orifice flow conditions existed at the bridge. The Bridge Waterways Analysis Model Research Report (Shearman, et al., 1986) indicates that orifice flow (type 2) occurs when the water surface is in contact with the low steel at the upstream bridge face only. A composite model was developed for the 100- and 500-year discharges. From this model it was determined that even though the water surface may be in contact with the low steel at the upstream face of the bridge, the water surface profile does pass through critical depth within the bridge opening. Therefore, the assumptions of critical depth are satisfactory solutions. 


\section{Bridge Hydraulics Summary}

$\begin{array}{llll}\text { Average bridge embankment elevation } & 501.4 \\ \text { Average low steel elevation } & 497.0 & \boldsymbol{f t}\end{array}$

100-year discharge $\quad 1,300 \quad \mathrm{ft}^{3} / \mathrm{s}$

Water-surface elevation in bridge opening $497.0 \quad f t$

Road overtopping? __ No Discharge over road _ _ $\quad 0$, s

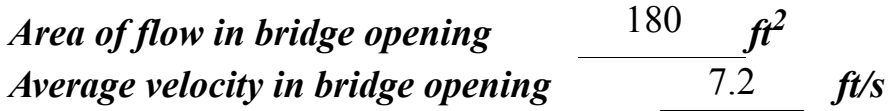

$\begin{array}{lll}\text { Maximum WSPRO tube velocity at bridge } & 9.1 \mathrm{ft} / \mathrm{s}\end{array}$

Water-surface elevation at Approach section with bridge 498.1

Water-surface elevation at Approach section without bridge $\quad 494.2$

Amount of backwater caused by bridge

3.9 it

500-year discharge $\quad 1,780 \quad \mathrm{ft}^{3} / \mathrm{s}$

Water-surface elevation in bridge opening $\quad 497.0 \mathrm{ft}$

Road overtopping? ___ No Discharge over road __ $\quad 0$ _/s

\begin{tabular}{llll} 
Area of flow in bridge opening & 180 & $\boldsymbol{f t}^{2}$ & \\
\cline { 2 - 4 } Average velocity in bridge opening & & $9.9 \quad \mathrm{ft} / \mathrm{s}$
\end{tabular}

Maximum WSPRO tube velocity at bridge 12.5 , s

Water-surface elevation at Approach section with bridge 500.1

Water-surface elevation at Approach section without bridge $\quad 495.2$

Amount of backwater caused by bridge 4.9 .

Incipient overtopping discharge ___ -- $f^{3} / \mathrm{s}$

Water-surface elevation in bridge opening $\quad--\quad t$

Area of flow in bridge opening _ $\quad--\quad \mathrm{ft}^{2}$

Average velocity in bridge opening $\quad--\quad f t / s$

Maximum WSPRO tube velocity at bridge _-- $\mathrm{ft} / \mathrm{s}$

Water-surface elevation at Approach section with bridge

Water-surface elevation at Approach section without bridge

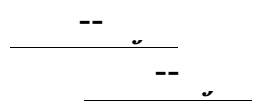
Amount of backwater caused by bridge _ 


\section{Scour Analysis Summary}

\section{Special Conditions or Assumptions Made in Scour Analysis}

Scour depths were computed using the general guidelines described in Hydraulic Engineering Circular 18 (Richardson and others, 1995). Scour depths were calculated assuming an infinite depth of erosive material and a homogeneous particle-size distribution. The results of the scour analysis are presented in tables 1 and 2 and a graph of the scour depths is presented in figure 8 .

Contraction scour was computed by use of Chang's pressure-flow scour equation for the 100- and 500-year discharges. The Chang equation is recommended at bridges with orifice flow (oral communication, J. Sterling Jones, October 4, 1996 and Richardson and others, 1995, p. 145-146). Although an unusual low steel configuration exists at this site, the 100- and 500-year discharges are assumed to result in unsubmerged orifice flow. Results of this analysis are presented in figure 8 and tables 1 and 2. The streambed armoring depths computed suggest that armoring will not limit the depth of contraction scour.

Contraction scour for each discharge modeled also was computed by use of Laursen's clear-water scour equation (Richardson and others, 1995, p. 32, equation 20) and the results are presented in Appendix F. Furthermore, contraction scour was computed substituting the critical depth in the bridge and the average main channel depth at the full valley section individually for the average depth in the contracted section. Contration scour results with respect to these substitutions also are provided in Appendix F.

Abutment scour at all modelled discharges was computed by use of the Froehlich equation (Richardson and others, 1995, p. 48, equation 28). Variables for the Froehlich equation include the Froude number of the flow approaching the embankments, the length of the embankment blocking flow, and the depth of flow approaching the embankment less any roadway overtopping. 


\section{Scour Results}

100-yr discharge 500-yr discharge

Incipient

Contraction scour:

(Scour depths in feet)

Main channel

Live-bed scour

Clear-water scour

Depth to armoring

Left overbank

Right overbank

Local scour:

Abutment scour

Left abutment

9.5

9.6

$13.6-$

16.7-

\section{Right abutment}

Pier scour

Pier 1

Pier 2

Pier 3

Abutments:

Left abutment

Right abutment

Piers:

Pier 1

Pier 2

overtopping discharge 


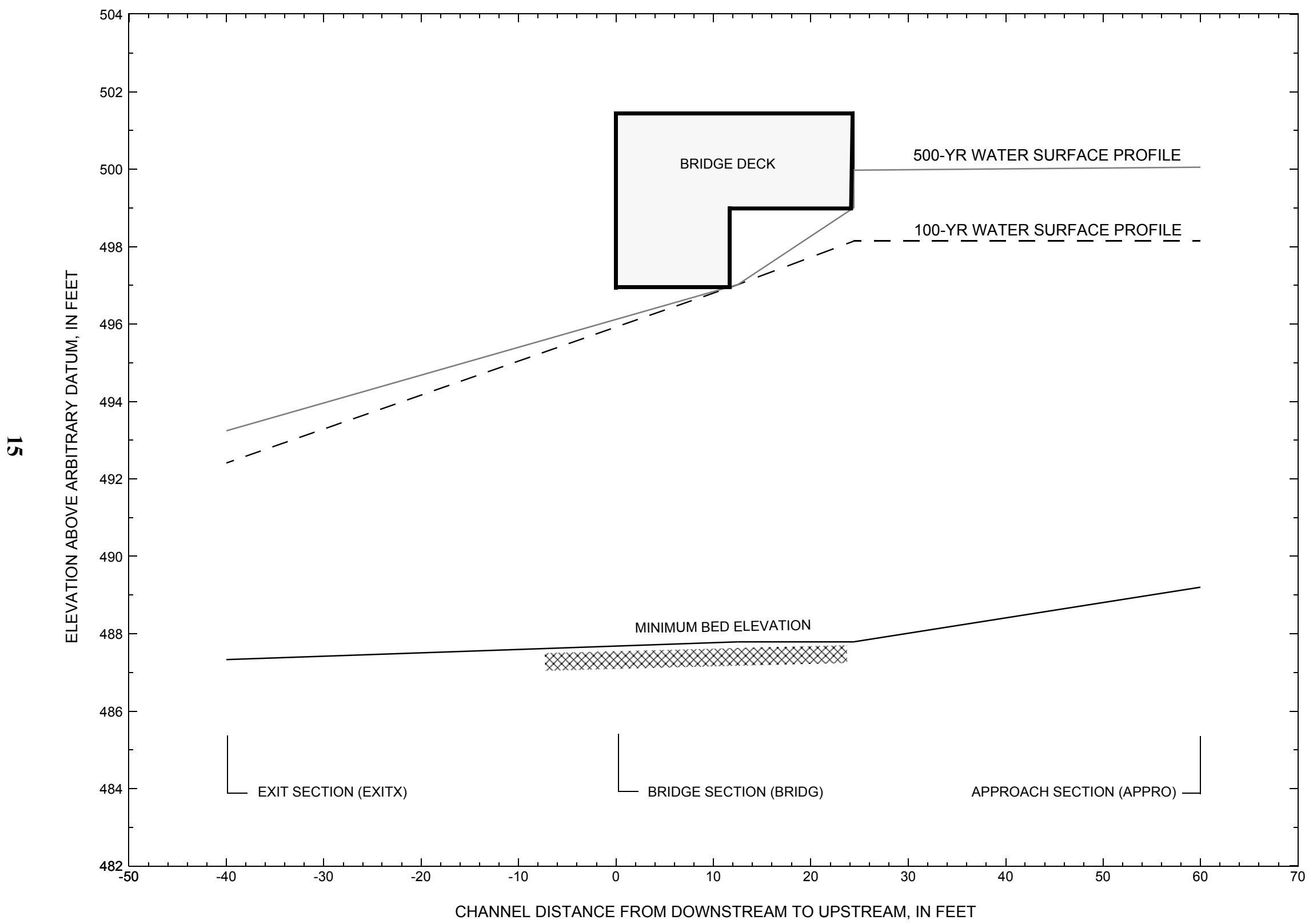

Figure 7. Water-surface profiles for the 100- and 500-yr discharges at structure CHARTH00390019 on town highway 39, crossing Mad Brook, Charleston, Vermont. 


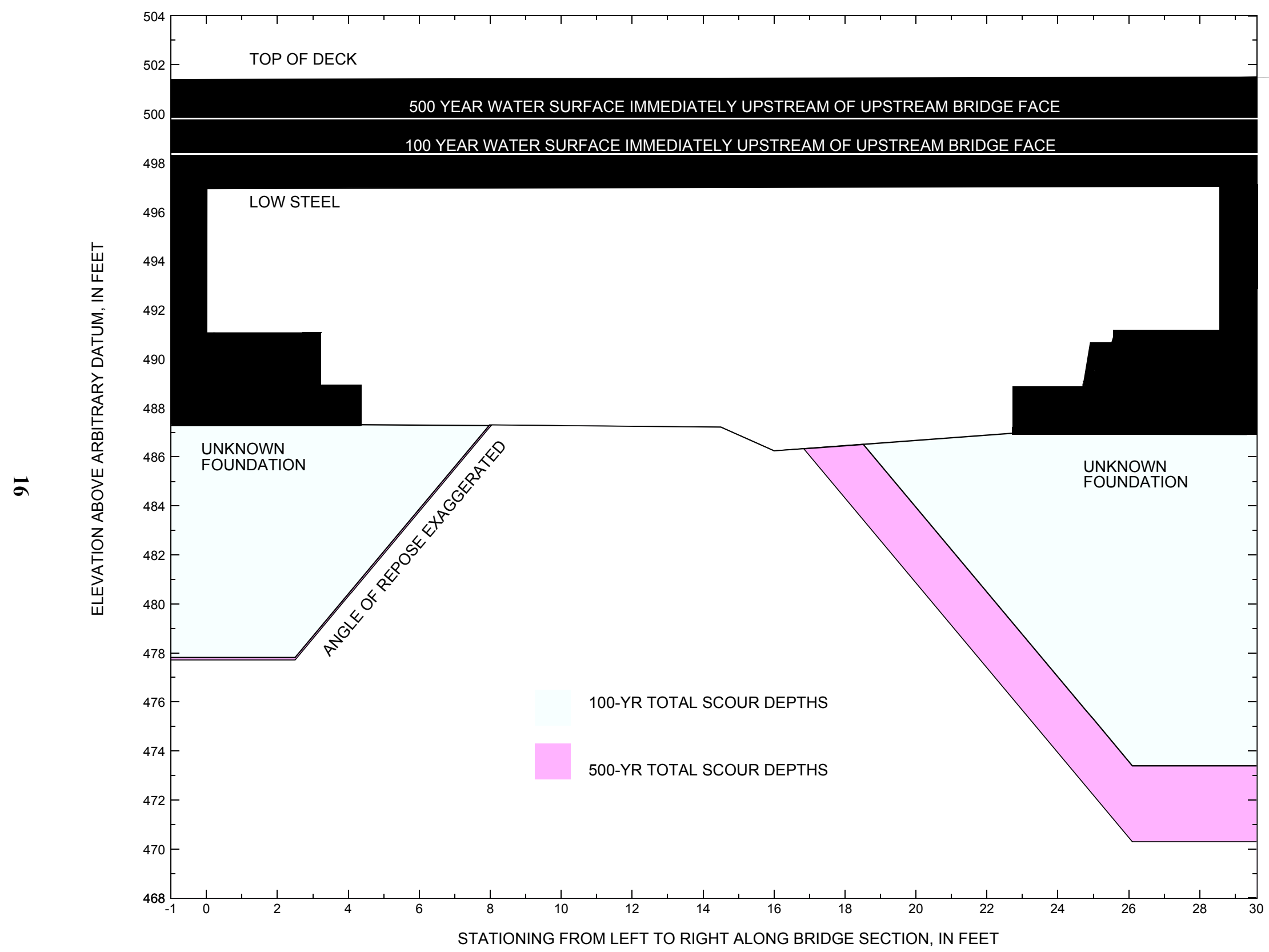

Figure 8. Scour elevations for the 100-yr and 500-yr discharges at structure CHARTH00390019 on town highway 39, crossing Mad Brook, Charleston, Vermont. 
Table 1. Remaining footing/pile depth at abutments for the 100-year discharge at structure CHARTH00390019 on Town Highway 39, crossing Mad Brook, Charleston, Vermont.

[VTAOT, Vermont Agency of Transportation; --,no data]

\begin{tabular}{|c|c|c|c|c|c|c|c|c|c|c|c|}
\hline Description & Station $^{1}$ & $\begin{array}{l}\text { VTAOT } \\
\text { minimum } \\
\text { low-chord } \\
\text { elevation } \\
\text { (feet) }\end{array}$ & $\begin{array}{l}\text { Surveyed } \\
\text { minimum } \\
\text { low-chord } \\
\text { elevation } \\
\quad \text { (feet) }\end{array}$ & $\begin{array}{l}\text { Bottom of } \\
\text { footing } \\
\text { elevation } \\
\text { (feet) }\end{array}$ & $\begin{array}{c}\text { Channel } \\
\text { elevation at } \\
\text { abutment/ } \\
\text { pier }^{2} \\
\text { (feet) }\end{array}$ & $\begin{array}{l}\text { Contraction } \\
\text { scour depth } \\
\text { (feet) }\end{array}$ & $\begin{array}{l}\text { Abutment } \\
\text { scour } \\
\text { depth } \\
\text { (feet) }\end{array}$ & $\begin{array}{l}\text { Pier } \\
\text { scour } \\
\text { depth } \\
\text { (feet) }\end{array}$ & $\begin{array}{l}\text { Depth of } \\
\text { total scour } \\
\text { (feet) }\end{array}$ & $\begin{array}{c}\text { Elevation of } \\
\text { scour }^{2} \\
\text { (feet) }\end{array}$ & $\begin{array}{c}\text { Remaining } \\
\text { footing/pile } \\
\text { depth } \\
\text { (feet) }\end{array}$ \\
\hline \multicolumn{12}{|c|}{100 -yr. discharge is 1,300 cubic-feet per second } \\
\hline Left abutment & 0.0 & -- & 497.0 & -- & 487.3 & 0.0 & 9.5 & -- & 9.5 & 477.8 & -- \\
\hline Right abutment & 28.6 & -- & 497.0 & -- & 487.0 & 0.0 & 13.6 & -- & 13.6 & 473.4 & -- \\
\hline
\end{tabular}

1. Measured along the face of the most constricting side of the bridge.

2. Arbitrary datum for this study.

Table 2. Remaining footing/pile depth at abutments for the 500-year discharge at structure CHARTH00390019 on Town Highway 39, crossing Mad Brook, Charleston, Vermont.

[VTAOT, Vermont Agency of Transportation; --, no data]

\begin{tabular}{|c|c|c|c|c|c|c|c|c|c|c|c|}
\hline Description & Station $^{1}$ & $\begin{array}{l}\text { VTAOT } \\
\text { minimum } \\
\text { low-chord } \\
\text { elevation } \\
\text { (feet) }\end{array}$ & $\begin{array}{l}\text { Surveyed } \\
\text { minimum } \\
\text { low-chord } \\
\text { elevation } \\
\quad \text { (feet) }\end{array}$ & $\begin{array}{l}\text { Bottom of } \\
\text { footing } \\
\text { elevation } \\
\text { (feet) }\end{array}$ & $\begin{array}{c}\text { Channel } \\
\text { elevation at } \\
\text { abutment/ } \\
\text { pier }^{2} \\
\text { (feet) }\end{array}$ & $\begin{array}{l}\text { Contraction } \\
\text { scour depth } \\
\text { (feet) }\end{array}$ & $\begin{array}{l}\text { Abutment } \\
\text { scour } \\
\text { depth } \\
\text { (feet) }\end{array}$ & $\begin{array}{l}\text { Pier } \\
\text { scour } \\
\text { depth } \\
\text { (feet) }\end{array}$ & $\begin{array}{l}\text { Depth of } \\
\text { total scour } \\
\text { (feet) }\end{array}$ & $\begin{array}{c}\text { Elevation of } \\
\text { scour }^{2} \\
\text { (feet) }\end{array}$ & $\begin{array}{c}\text { Remaining } \\
\text { footing/pile } \\
\text { depth } \\
\text { (feet) }\end{array}$ \\
\hline \multicolumn{12}{|c|}{500 -yr. discharge is 1,780 cubic-feet per second } \\
\hline Left abutment & 0.0 & -- & 497.0 & -- & 487.3 & 0.0 & 9.6 & -- & 9.6 & 477.7 & -- \\
\hline Right abutment & 28.6 & -- & 497.0 & -- & 487.0 & 0.0 & 16.7 & -- & 16.7 & 470.3 & -- \\
\hline
\end{tabular}

1. Measured along the face of the most constricting side of the bridge.

2. Arbitrary datum for this study. 


\section{SELECTED REFERENCES}

Arcement, G.J., Jr., and Schneider, V.R., 1989, Guide for selecting Manning's roughness coefficients for natural channels and flood plains: U.S. Geological Survey Water-Supply Paper 2339, 38 p.

Barnes, H.H., Jr., 1967, Roughness characteristics of natural channels: U.S. Geological Survey Water-Supply Paper 1849, $213 \mathrm{p}$.

Benson, M. A., 1962, Factors Influencing the Occurrence of Floods in a Humid Region of Diverse Terrain: U.S. Geological Survey Water-Supply Paper 1580-B, 64 p.

Brown, S.A. and Clyde, E.S., 1989, Design of riprap revetment: Federal Highway Administration Hydraulic Engineering Circular No. 11, Publication FHWA-IP-89-016, 156 p.

Federal Highway Administration, 1983, Runoff estimates for small watersheds and development of sound design: Federal Highway Administration Report FHWA-RD-77-158

Froehlich, D.C., 1989, Local scour at bridge abutments in Ports, M.A., ed., Hydraulic Engineering--Proceedings of the 1989 National Conference on Hydraulic Engineering: New York, American Society of Civil Engineers, p. 13-18.

Hayes, D.C.,1993, Site selection and collection of bridge-scour data in Delaware, Maryland, and Virginia: U.S. Geological Survey Water-Resources Investigation Report 93-4017, 23 p.

Johnson, C.G. and Tasker, G.D.,1974, Progress report on flood magnitude and frequency of Vermont streams: U.S. Geological Survey Open-File Report 74-130, 37 p.

Lagasse, P.F., Schall, J.D., Johnson, F., Richardson, E.V., Chang, F., 1995, Stream Stability at Highway Structures: Federal Highway Administration Hydraulic Engineering Circular No. 20, Publication FHWA-IP-90-014, 144 p.

Laursen, E.M., 1960, Scour at bridge crossings: Journal of the Hydraulics Division, American Society of Civil Engineers, v. 86 , no. HY2, p. 39-53.

Potter, W. D., 1957, Peak rates of runoff in the New England Hill and Lowland area, Bureau of Public Roads

Richardson, E.V. and Davis, S.R., 1995, Evaluating scour at bridges: Federal Highway Administration Hydraulic Engineering Circular No. 18, Publication FHWA-IP-90-017, 204 p.

Richardson, E.V., Simons, D.B., and Julien, P.Y., 1990, Highways in the river environment: Federal Highway Administration Publication FHWA-HI-90-016.

Ritter, D.F., 1984, Process Geomorphology: W.C. Brown Co., Debuque, Iowa, 603 p.

Shearman, J.O., 1990, User's manual for WSPRO--a computer model for water surface profile computations: Federal Highway Administration Publication FHWA-IP-89-027, 187 p.

Shearman, J.O., Kirby, W.H., Schneider, V.R., and Flippo, H.N., 1986, Bridge waterways analysis model: research report; Federal Highway Administration Publication FHWA-RD-86-108, 112 p.

Talbot, A.N., 1887, The determination of water-way for bridges and culverts.

U.S. Department of Transportation, 1993, Stream stability and scour at highway bridges, Participant Workbook: Federal Highway Administration Publication FHWA HI-91-011.

U.S. Geological Survey, 1988, Island Pond, Vermont 7.5 Minute Series quadrangle map: U.S. Geological Survey Topographic Maps; Aerial Photography, 1983; Contour interval, 20 feet; Scale 1:24,000. 


\section{APPENDIX A: \\ WSPRO INPUT FILE}




\section{WSPRO INPUT FILE}

XS

GR

GR

GR

GR

GR

$\mathrm{N}$

SA

XS

BR

GR

GR

GR

GR

GR

$\mathrm{N}$

CD

XR

GR

GR

GR

*

$\mathrm{XT}$

GR

GR

GR

GR

GR

GR

*

AS

GT

$\mathrm{N}$

SA

HP 1 BRIDG

HP 2 BRIDG

HP 1 BRIDG

HP 2 BRIDG

HP 1 APPRO

HP 2 APPRO

*

HP 1 BRIDG

HP 2 BRIDG

HP 1 BRIDG

HP 2 BRIDG

HP 1 APPRO

HP 2 APPRO

*

EX

ER

U.S. Geological Survey WSPRO Input File char019.wsp

Hydraulic analysis for structure CHARTH00390019 Date: 08-MAY-96

Town Highway 39 Bridge Crossing of Mad Brook, Charleston, VT $1300.0 \quad 1780.0$

$0.0230 \quad 0.0230$

$\begin{array}{lllllllllllllllllllll}6 & 29 & 30 & 552 & 553 & 551 & 5 & 16 & 17 & 13 & 3 & * & 15 & 14 & 23 & 21 & 11 & 12 & 4 & 7 & 3\end{array}$

$\begin{array}{rrrr}-40 & & & \\ -70.6, & 494.45 & -52.8, & 494.15 \\ -2.7, & 492.39 & 0.0, & 488.39 \\ 11.8, & 487.33 & 21.5, & 487.50 \\ 37.4, & 491.73 & 45.1, & 494.85 \\ 151.8, & 501.39 & 245.1, & 504.43 \\ 0.095 & 0.060 & 0.095\end{array}$

$$
\begin{array}{r}
-32.1,493.13 \\
3.5,487.95 \\
21.9,488.38 \\
70.9,498.40
\end{array}
$$

0.045

70.9

$$
-2.7
$$

21.9

$0.2,491.05$

$4.0,487.31$

$23.0,486.99$

$25.5,490.55$

$0.0,497.02$

$28.6,496.98$

0.050

146.4 * 595.3

RDWAY $\quad 20 \quad 24.4 \quad 2$

$-148.4,506.65$

$0.0,501.34$

$124.4,500.97$

$\begin{array}{rr}-117.1, & 502.99 \\ 27.6, & 501.56 \\ 178.6, & 503.03\end{array}$

$-93.1,503.92$

$-7.0,495.92$

$8.8,490.57$

$21.2,490.60$

$64.7,494.61$

$33.1,494.25$

$109.5,503.13$

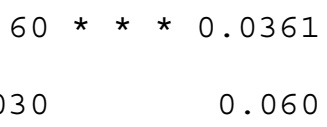

0.060

0.030

$-19.1$

33.1

493.151493 .15

$493.15 *$ * 1300

497.021497 .02

497.02 * $* 1300$

$498.14 \quad 1 \quad 498.14$

$498.14 * * 1300$

494.291494 .29

494.29 * 1780

497.021497 .02

497.02 * * 1780

500.051500 .05

$500.05 * * 1780$
$2.8,490.83$

$10.1,487.29$

$23.1,488.70$

$25.6,491.02$

$-80.4,501.98$

$67.3,500.68$

$201.3, \quad 507.11$

$$
\begin{array}{rr}
-32.2, & 500.63 \\
-2.2, & 491.52 \\
10.8, & 490.07 \\
26.0, & 491.16 \\
83.6, & 493.89
\end{array}
$$

0.080

$$
\begin{array}{r}
-13.5,492.26 \\
6.1, \quad 487.88 \\
32.9, \quad 488.70 \\
114.6, \quad 499.54
\end{array}
$$

$3.1,488.79$

$14.5,487.21$

$24.8,488.74$

$28.6,491.01$

$-39.9,501.04$

$90.9,500.50$

$-19.1,500.26$

$0.0,490.62$

$15.3,489.52$

$29.7,491.35$

$94.3,493.77$

EMB 


\section{APPENDIX B: \\ WSPRO OUTPUT FILE}




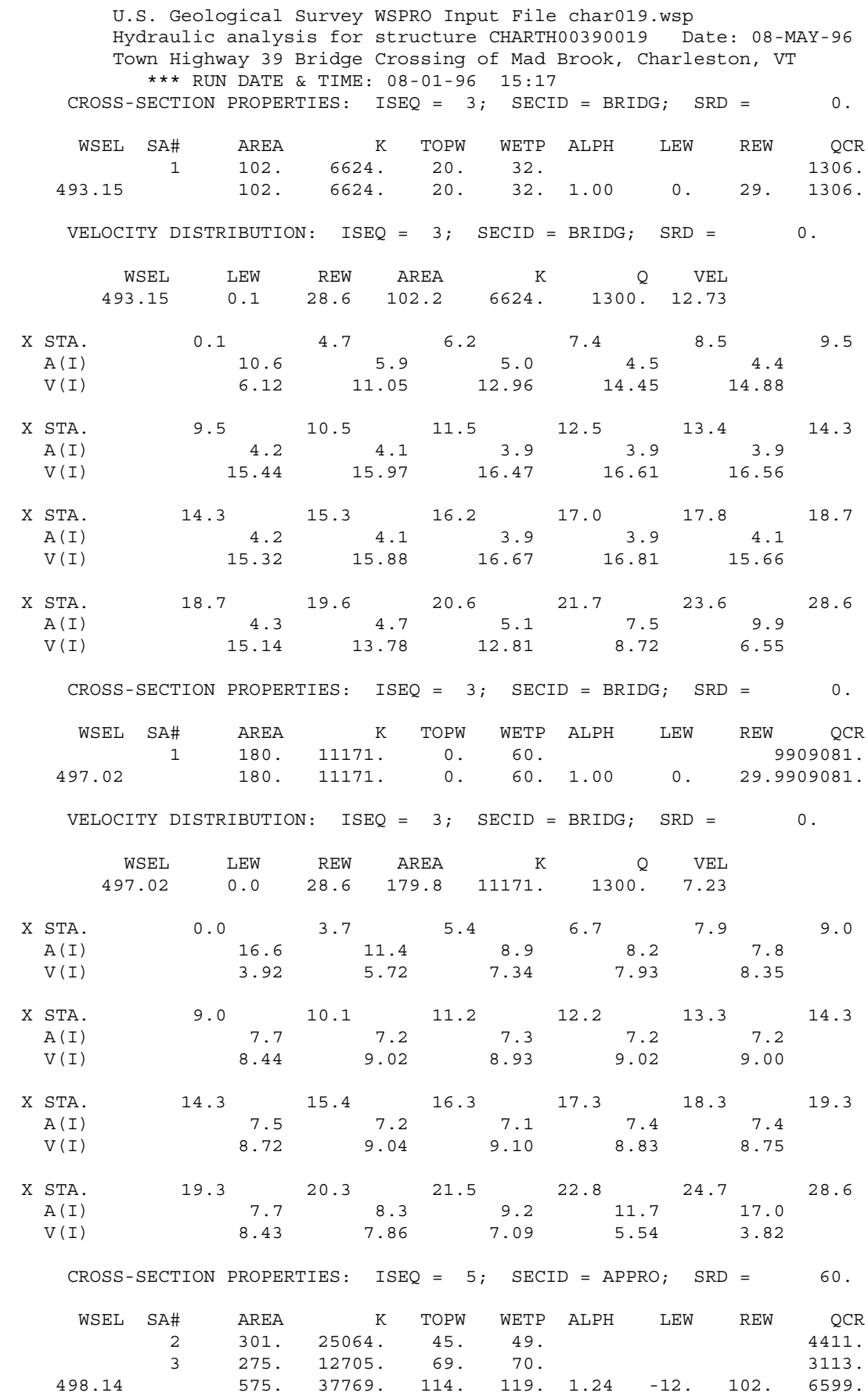

VELOCITY DISTRIBUTION: ISEQ $=5 ;$ SECID $=$ APPRO; $\operatorname{SRD}=60$.

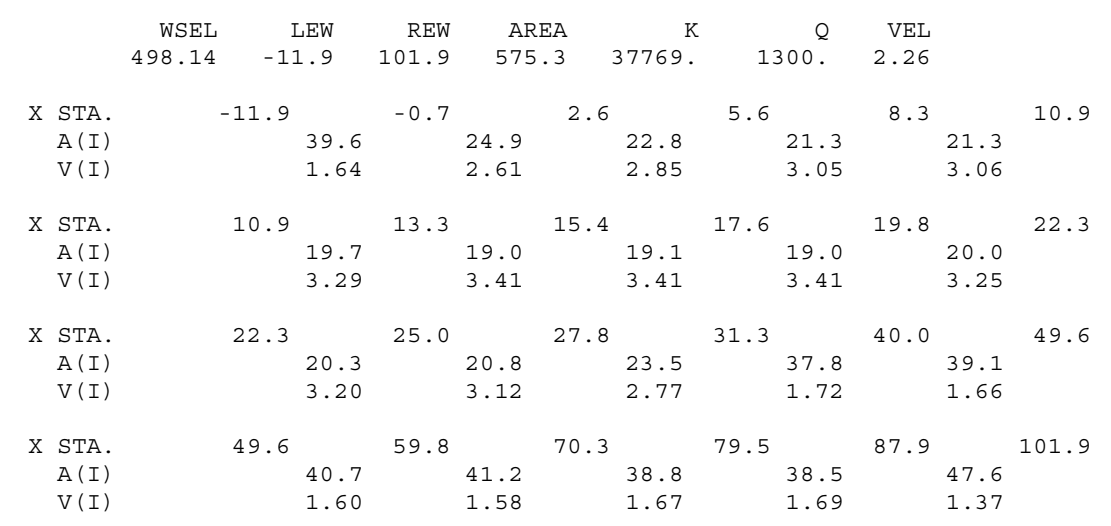




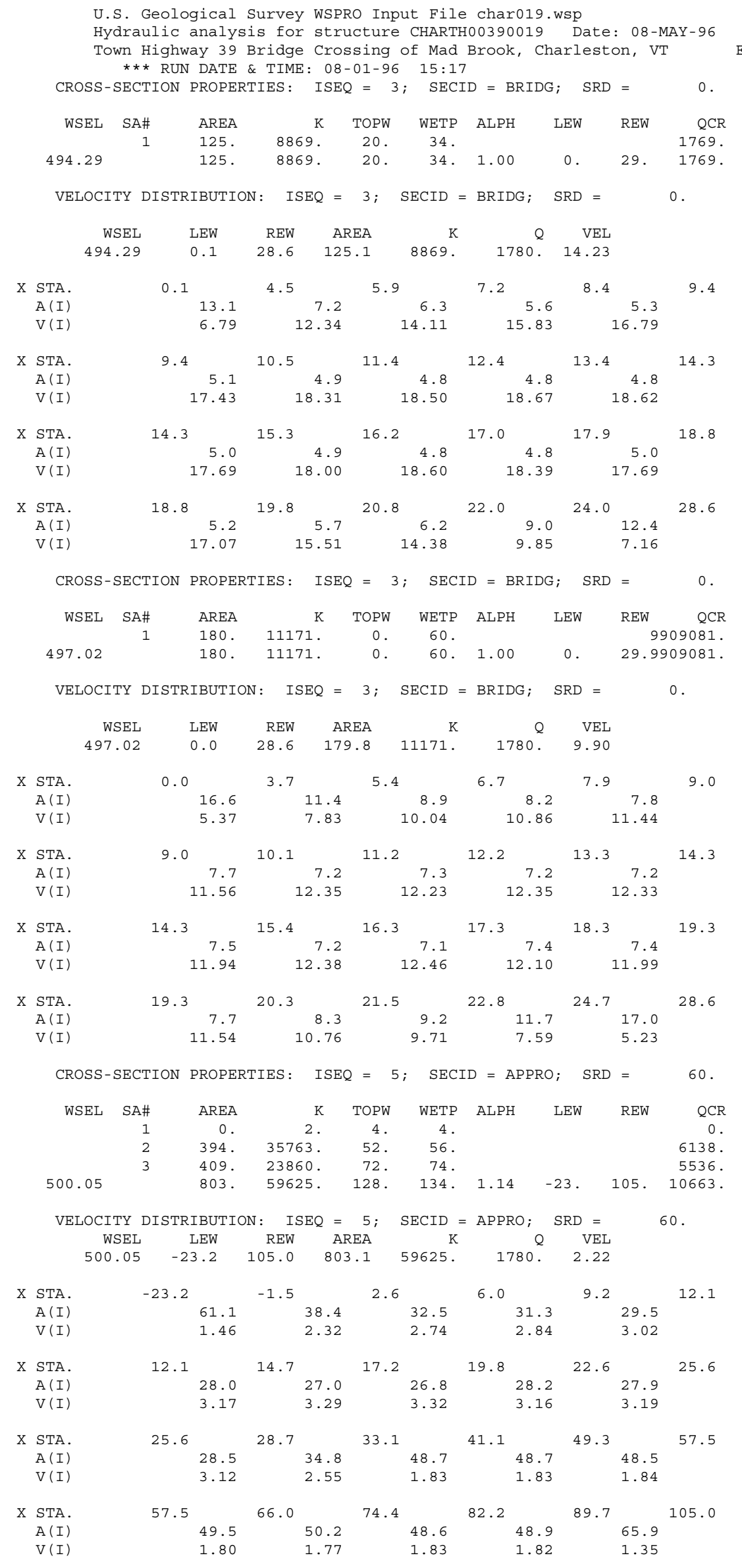


WSPRO OUTPUT FILE (continued)

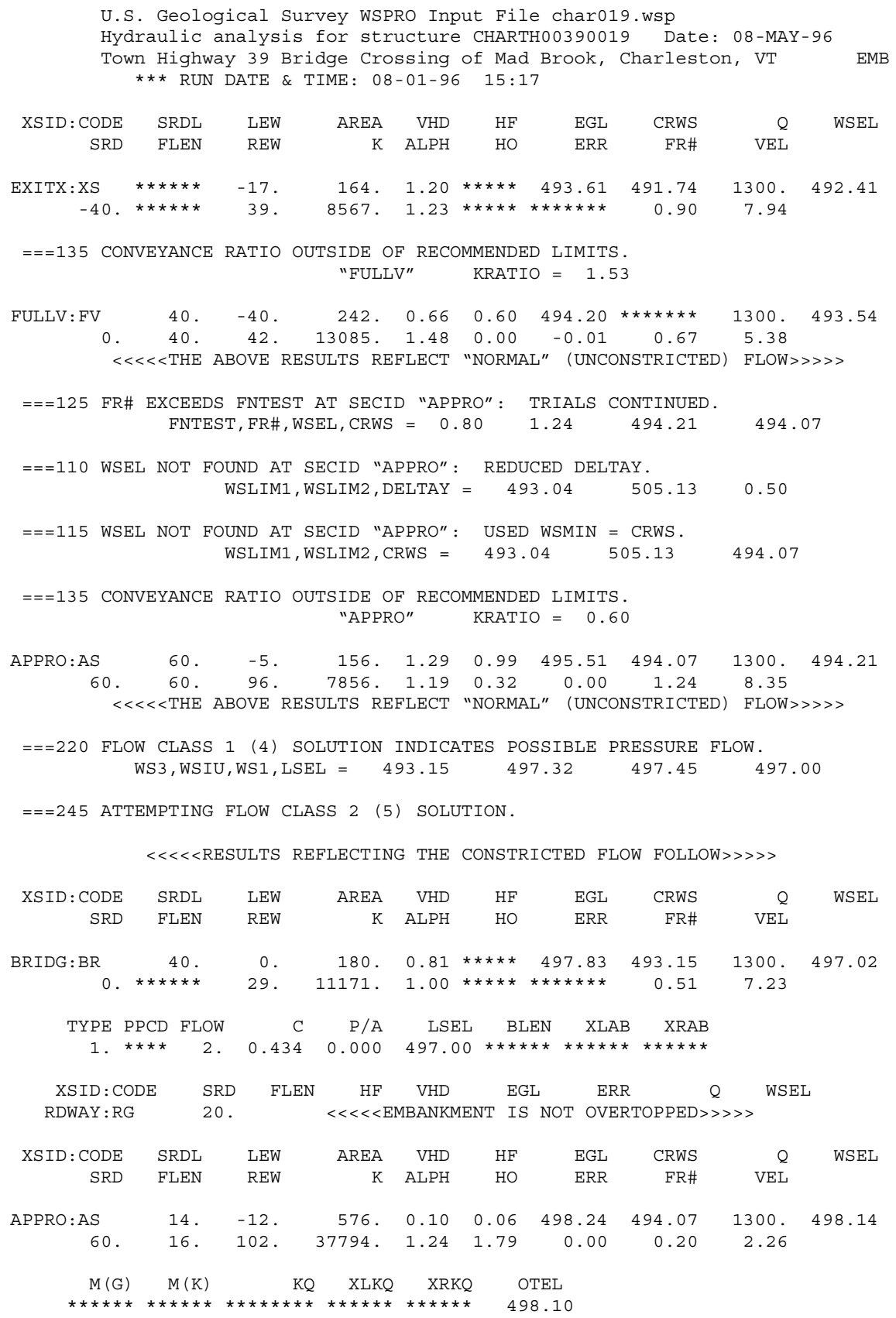

$<<<<$ END OF BRIDGE COMPUTATIONS $>>>>>$

FIRST USER DEFINED TABLE.

\begin{tabular}{|c|c|c|c|c|c|c|c|c|}
\hline XSID : CODE & SRD & LEW & REW & $Q$ & K & AREA & VEL & WSEL \\
\hline EXITX:XS & -40 & -17. & 39. & 1300. & 8567. & 164. & 7.94 & 492.41 \\
\hline FULLV : FV & 0 . & -40 & 42 . & 1300. & 13085 . & 242 . & 5.38 & 493.54 \\
\hline BRIDG : BR & 0 . & 0 . & 29. & 1300. & 11171. & 180. & 7.23 & 497.02 \\
\hline RDWAY : RG & 20. & $* \star \star * \star * *$ & $* * * *$ & 0 . & \multicolumn{2}{|c|}{$0 . * * \star \star \star * \star * \star * *$} & \multicolumn{2}{|c|}{$2.00 * * * * * * * *$} \\
\hline APPRO : AS & 60. & -12 & 102. & 1300 . & 37794 . & 576. & 2.26 & 498.14 \\
\hline XSID : CODE & XLKQ & XRKQ & \multicolumn{2}{|c|}{$\mathrm{KQ}$} & & & & \\
\hline APPRO : AS & & & & & & & & \\
\hline
\end{tabular}

SECOND USER DEFINED TABLE.

$\begin{array}{lcrrrrrrrr}\text { XSID : CODE } & \text { CRWS } & \text { FR\# } & \text { YMIN } & \text { YMAX } & \text { HF } & \text { HO } & \text { VHD } & \text { EGL } & \text { WSEL } \\ \text { EXITX:XS } & 491.74 & 0.90 & 487.33 & 504.43 * * * * * * * * * * & 1.20 & 493.61 & 492.41 \\ \text { FULLV : FV } & * * * * * * * * & 0.67 & 487.33 & 504.43 & 0.60 & 0.00 & 0.66 & 494.20 & 493.54 \\ \text { BRIDG : BR } & 493.15 & 0.51 & 486.24 & 497.02 * * * * * * * * * * & 0.81 & 497.83 & 497.02 \\ \text { RDWAY : RG } & * * * * * * * * * * * * * * * * & 500.50 & 507.11 * * * * * * * * * * * & 0.03 & 501.09 * * * * * * * \\ \text { APPRO : AS } & 494.07 & 0.20 & 489.20 & 505.13 & 0.06 & 1.79 & 0.10 & 498.24 & 498.14\end{array}$


WSPRO OUTPUT FILE (continued)

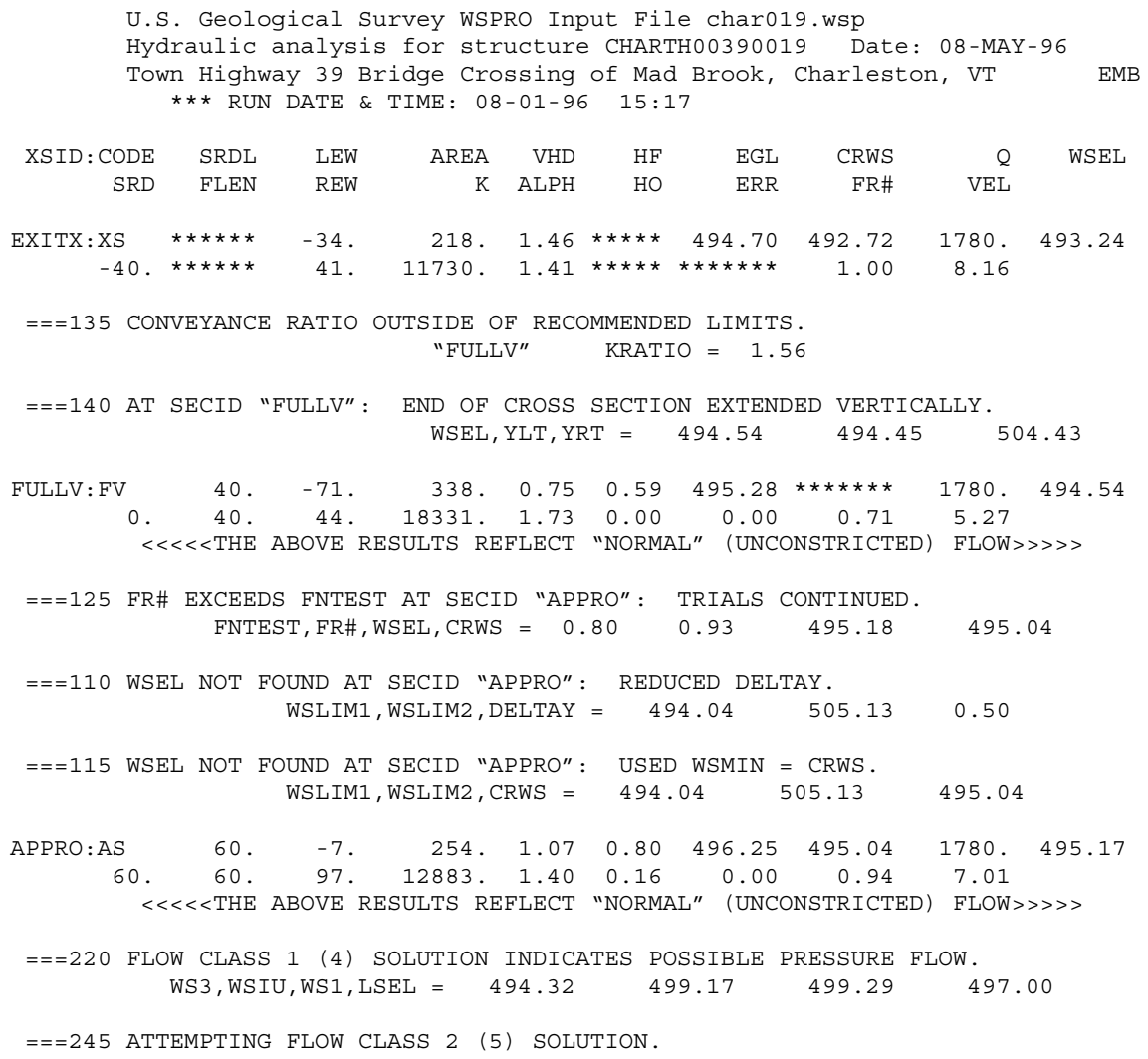




\section{APPENDIX C:}

\section{BED-MATERIAL PARTICAL-SIZE DISTRIBUTION}




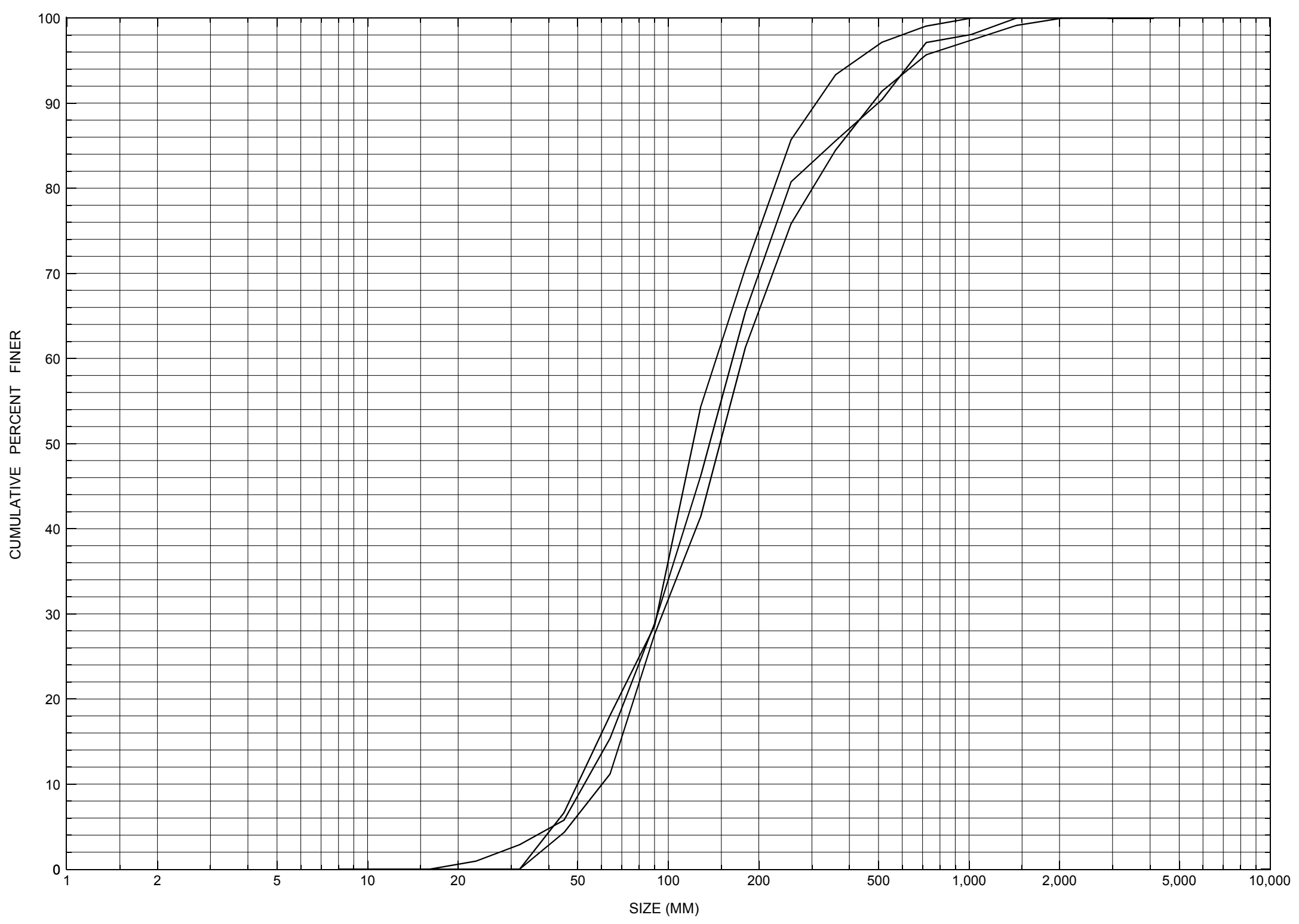

Appendix C. Bed material particle-size distributions for three pebble count transects at the approach cross-section for structure CHARTH00390019, in Charleston, Vermont. 


\section{APPENDIX D: \\ HISTORICAL DATA FORM}




\section{Structure Number CHARTH00390019}

\section{General Location Descriptive}

Data collected by (First Initial, Full last name) M. WEBER

Date $(M M / D D / Y Y) \_\mathbf{0 8} / \underline{\mathbf{0 4}} / \underline{\mathbf{9 4}}$

Highway District Number (I - 2; nn) 09

Town (FIPS place code; I - 4; nnnnn) 13150

Waterway (I - 6) Mad Brook

Route Number TH039

Topographic Map Island.Pond

Latitude (I - 16; nnnn.n) $\mathbf{4 4 4 8 8}$
County (FIPS county code; $I-3 ;$ nnn)

Mile marker (I - 11; nnn.nnn) $\mathbf{0 0 0 0 0 0}$

Road Name (I - 7): -

Vicinity (I - 9) 0.3 MI TO JCT W CL2 TH1

Hydrologic Unit Code: $\mathbf{0 1 1 1 0 0 0 0}$

Longitude (i - 17; nnnnn.n) $\mathbf{7 1 5 8 4}$

\section{Select Federal Inventory Codes}

FHWA Structure Number (I - 8) $\mathbf{1 0 1 0 0 4 0 0 1 9 1 0 0 4}$

Maintenance responsibility $(I-21 ; n n)$

Year built (I - 27; YYYY) 1940

Average daily traffic, ADT (I - 29; nnnnnn) 000250

Year of ADT (I - 30; YY) $\mathbf{9 0}$

Opening skew to Roadway $(I-34 ; n n) \quad 45$

Operational status $(I-41 ; X)$ A

Structure type (I - 43; nnn) 101

Approach span structure type (I - 44; nnn) $\mathbf{0 0 0}$

Number of spans (I - 45; nnn) $\mathbf{0 0 1}$

Number of approach spans (I - 46; nnnn) $\mathbf{0 0 0 0}$

Comments:

Structural inspection of 6/17/94 indicates a concrete slab type bridge. Numerous subfootings were constructed due to ongoing channel scour. The abutments and wingwalls are stable with no apparent settlement. Heavy embankment erosion is noted downstream. Stone fill is noted as needed along the right abutment. There is a slight channel turn into the bridge with a somewhat constrictive opening. A boulder bar is reported on the upstream left bank.
Maximum span length (I - 48; nnnn) $\underline{\mathbf{0 0 3 1}}$

Structure length (I - 49; nnnnnn) $\underline{000034}$

Deck Width (I - 52; nn.n) 244

Channel \& Protection $(I-61 ; n) \underline{5}$

Waterway adequacy $(I-71 ; n) \underline{6}$

Underwater Inspection Frequency $(I-92 B ; X Y Y) \_$N

Year Reconstructed (I - 106) 1969

Clear span (nnn.n ft) _ _

Vertical clearance from streambed (nnn.n ft) $\underline{\mathbf{0 1 0 . 5}}$

Waterway of full opening $\left(n n n . n \mathrm{ft}^{2}\right)$ 


\section{Bridge Hydrologic Data}

Is there hydrologic data available? $\underline{\mathbf{N}}$ if No, type ctrl- $n$ VTAOT Drainage area $\left(\mathrm{mi}^{2}\right)$ : -

Terrain character:

Stream character \& type: -

Streambed material: Boulders and gravel

Discharge Data (cfs): $\quad Q_{2.33}$

$$
\mathrm{Q}_{50}-
$$

Record flood date $(M M / D D / Y Y):-$

$\begin{array}{ll}Q_{10}- & Q_{25}- \\ Q_{100 \_-} & Q_{500-}-\end{array}$

Water surface elevation $(f t):-$

Estimated Discharge (cfs):

Velocity at $\mathrm{Q}-$ $(\mathrm{ft} / \mathrm{s}):$

Ice conditions (Heavy, Moderate, Light) : Light

Debris (Heavy, Moderate, Light): Light

The stage increases to maximum highwater elevation (Rapidly, Not rapidly):

The stream response is (Flashy, Not flashy):

Describe any significant site conditions upstream or downstream that may influence the stream's stage: -

Watershed storage area (in percent): - _ \%

The watershed storage area is: - (1-mainly at the headwaters; 2- uniformly distributed; 3-immediatly upstream oi the site)

Water Surface Elevation Estimates for Existing Structure:

\begin{tabular}{|l|l|l|l|l|l|}
\hline Peak discharge frequency & $Q_{2.33}$ & $Q_{10}$ & $Q_{25}$ & $Q_{50}$ & $Q_{100}$ \\
Water surface elevation (ft)) & - & - & - & - & - \\
Velocity (ft/sec) & - & - & - & - & - \\
\hline
\end{tabular}

Long term stream bed changes: -

Is the roadway overtopped below the $Q_{100}$ ? (Yes, No, Unknown):

Frequency: -

Relief Elevation (ft):

Discharge over roadway at $Q_{100}\left(f^{3} / \mathrm{sec}\right)$ :

Are there other structures nearby? (Yes, No, Unknown): $\mathbf{U}$ Upstream distance (miles): Town: If No or Unknown, type ctrl-n os Highway No. : Structure No. : Year Built:

Clear span (ft): Clear Height $(f t)$ : Full Waterway $\left(f t^{2}\right)$ : 
Downstream distance (miles): Town: Year Built:

Highway No. : Structure No. : Structure Type:

Clear span $(f t):$ Clear Height $(f t)$ : Full Waterway $\left(f^{2}\right)$ : -

Comments:

Existing surface velocity at the time of the inspection was 2 feet/second.

\section{USGS Watershed Data}

Watershed Hydrographic Data

Drainage area $(D A)$

Watershed storage (ST)

Bridge site elevation

Main channel length

1280
$\mathrm{mi}^{2}$ ) $\%$ ft $\mathrm{mi}$ $10 \%$ channel length elevation $\mathbf{1 3 4 0}$

Main channel slope (S) (S) 328.32 $\mathrm{ft} / \mathrm{mi}$
Lake and pond area

0 $\mathrm{mi}^{2}$ Headwater elevation $\lcm{3300} \mathrm{ft}$ $\mathrm{ft} \quad 85 \%$ channel length elevation $\mathrm{ft}$

Watershed Precipitation Data

Average site precipitation in

Average headwater precipitation in

Maximum 2yr-24hr precipitation event $(124,2)$ in

Average seasonal snowfall (Sn) $\mathrm{ft}$ 


\section{Bridge Plan Data}

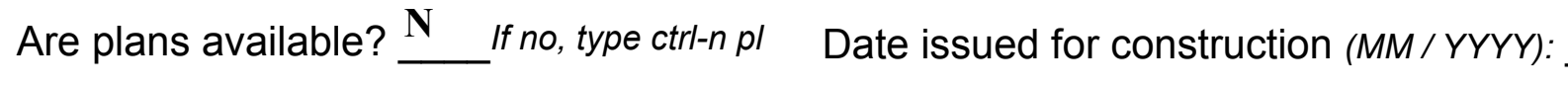

Project Number

Minimum channel bed elevation:

Low superstructure elevation: USLAB DSLAB USRAB DSRAB Benchmark location description:

Reference Point (MSL, Arbitrary, Other): Datum (NAD27, NAD83, Other):

Foundation Type: 4

If 1 : Footing Thickness

If 2: Pile Type: (1-Wood; 2-Steel or metal; 3-Concrete)

If 3 : Footing bottom elevation:

Is boring information available? $\mathbf{N}$ Foundation Material Type: $\mathbf{3}$ (1-Spreadfooting; 2-Pile; 3- Gravity; 4-Unknown) Footing bottom elevation: -

Briefly describe material at foundation bottom elevation or around piles:

NO FOUNDATION MATERIAL INFORMATION

Comments:

NO PLANS. 


\section{Cross-sectional Data}

Is cross-sectional data available? $\mathbf{N}$ If no, type ctrl-n xs

Source (FEMA, VTAOT, Other)? -

Comments: NO CROSS SECTION INFORMATION

\begin{tabular}{|l|l|l|l|l|l|l|l|l|l|l|l|}
\hline Station & - & - & - & - & - & - & - & - & - & - & - \\
\hline Feature & - & - & - & - & - & - & - & - & - & - & - \\
\hline $\begin{array}{l}\text { Low cord } \\
\text { elevation }\end{array}$ & - & - & - & - & - & - & - & - & - & - & - \\
\hline $\begin{array}{l}\text { Bed } \\
\text { elevation }\end{array}$ & - & - & - & - & - & - & - & - & - & - & - \\
\hline $\begin{array}{l}\text { Low cord to } \\
\text { bed length }\end{array}$ & - & - & - & - & - & - & - & - & - & - & - \\
\hline Station & - & - & - & - & - & - & - & - & - & - & - \\
\hline Feature & - & - & - & - & - & - & - & - & - & - & - \\
\hline $\begin{array}{l}\text { Low cord } \\
\text { elevation }\end{array}$ & - & - & - & - & - & - & - & - & - & - & - \\
\hline $\begin{array}{l}\text { Bed } \\
\text { elevation }\end{array}$ & - & - & - & - & - & - & - & - & - & - & - \\
\hline $\begin{array}{l}\text { Low cord to } \\
\text { bed length }\end{array}$ & - & - & - & - & - & - & - & - & - & - & - \\
\hline
\end{tabular}

Source (FEMA, VTAOT, Other)?

Comments: NO CROSS SECTION INFORMATION

\begin{tabular}{|l|l|l|l|l|l|l|l|l|l|l|l|}
\hline Station & - & - & - & - & - & - & - & - & - & - & - \\
\hline Feature & - & - & - & - & - & - & - & - & - & - & - \\
\hline $\begin{array}{l}\text { Low cord } \\
\text { elevation }\end{array}$ & - & - & - & - & - & - & - & - & - & - & - \\
\hline $\begin{array}{l}\text { Bed } \\
\text { elevation }\end{array}$ & - & - & - & - & - & - & - & - & - & - & - \\
\hline $\begin{array}{l}\text { Low cord to } \\
\text { bed length }\end{array}$ & - & - & - & - & - & - & - & - & - & - & - \\
\hline Station & - & - & - & - & - & - & - & - & - & - & - \\
\hline Feature & - & - & - & - & - & - & - & - & - & - & - \\
\hline $\begin{array}{l}\text { Low cord } \\
\text { elevation }\end{array}$ & - & - & - & - & - & - & - & - & - & - & - \\
\hline $\begin{array}{l}\text { Bed } \\
\text { levation }\end{array}$ & - & - & - & - & - & - & - & - & - & - & - \\
\hline $\begin{array}{l}\text { Low cord to } \\
\text { bed length }\end{array}$ & - & - & - & - & - & - & - & - & - & - & - \\
\hline
\end{tabular}




\section{APPENDIX E: \\ LEVEL I DATA FORM}


U. S. Geological Survey

Bridge Field Data Collection and Processing Form

Qa/Qc Check by: $\underline{\mathbf{R B}}$ Date: $2 / 12 / 96$

\section{Structure Number}

\section{A. General Location Descriptive}

1. Data collected by (First Initial, Full last name) R. HAMMOND

Date $(M M / D D / Y Y)$

$10 / 26$

1994

2. Highway District Number 09

County ORLEANS (019)

Waterway (I - 6) MAD BROOK

Route Number TH039

3. Descriptive comments:

Located about 0.3 miles from the junction of TH 39 with TH 1.
Mile marker $\mathbf{0}$

Town CHARLESTON (13150)

Road Name -

Hydrologic Unit Code: $\mathbf{0 1 1 1 0 0 0 0}$

\section{B. Bridge Deck Observations}
4. Surface cover... LBUS 6
RBUS 5
LBDS 6
RBDS 6
Overall 6

(2b us,ds,lb,rb: 1- Urban; 2- Suburban; 3- Row crops; 4- Pasture; 5- Shrub- and brushland; 6- Forest; 7- Wetland)
5. Ambient water surface...US 2
UB 1
DS 2
(1- pool; 2- riffle)

6. Bridge structure type 1 (1- single span; 2- multiple span; 3- single arch; 4- multiple arch; 5-cylindrical culvert; 6- box culvert; or 7- other)
7. Bridge length $\mathbf{3 4}$
(feet)
Span length $\underline{\mathbf{3 1}}$
(feet)
Bridge width 24.4 (feet)

\section{Road approach to bridge:}
8. LB 1
RB 2
( 0 even, 1- lower, 2- higher)
9. LB_2
RB $\underline{2}$
(1-Paved, 2- Not paved)

10. Embankment slope (run / rise in feet / foot)

$$
\text { US left }
$$

0.0:1

US right

0.0:1

\begin{tabular}{|c|c|c|c|c|}
\hline & \multicolumn{2}{|c|}{ Protection } & \multirow{2}{*}{ 13.Erosion } & \multirow{2}{*}{ 14.Severity } \\
\hline & 11.Type & 12.Cond. & & \\
\hline LBUS & 3 & 1 & $\mathbf{0}$ & $\mathbf{0}$ \\
\hline RBUS & $\mathbf{0}$ & - & 0 & $\mathbf{0}$ \\
\hline RBDS & 0 & - & $\mathbf{0}$ & $\mathbf{0}$ \\
\hline LBDS & $\mathbf{0}$ & - & $\mathbf{0}$ & $\mathbf{0}$ \\
\hline
\end{tabular}

Bank protection types: 0- none; 1- $<12$ inches;

2- < 36 inches; 3- < 48 inches;

4- < 60 inches; 5- wall / artificial levee

Bank protection conditions: 1- good; 2- slumped;

3- eroded; 4- failed

Erosion: 0 - none; 1- channel erosion; 2 -

road wash; 3- both; 4- other

Erosion Severity: 0 - none; 1- slight; 2- moderate; 3- severe

\section{Channel approach to bridge (BF):}

15. Angle of approach: 0

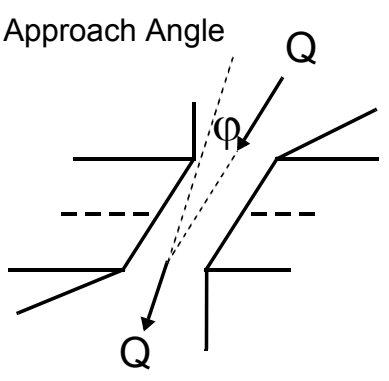

17. Channel impact zone 1 :

Where? LB $(L B, R B)$

Range? 165 feet $\underline{\text { US }}$

Channel impact zone 2:

Where? LB $(L B, R B)$

Range? 160 feet $\underline{\mathbf{D S}}$ (US, UB, DS) to $\underline{\mathbf{2 0 0}}$ feet $\underline{\mathbf{D S}}$

Impact Severity: 0- none to very slight; 1- Slight; 2- Moderate; 3- Severe
16. Bridge skew: $\underline{40}$ Bridge Skew Angle

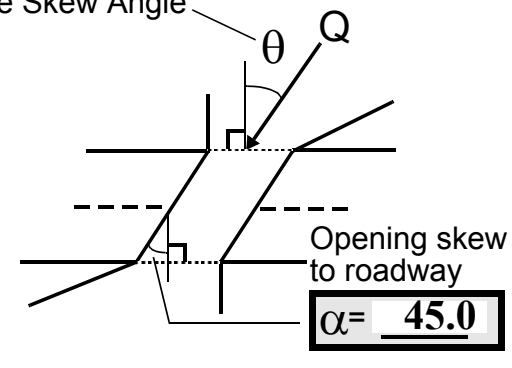

\section{Exist? $\mathbf{Y}(Y$ or $N)$}

Severity 1

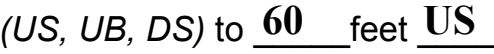

Exist? $\mathbf{Y}(Y$ or $N)$

Severity $\underline{2}$ 
18. Bridge Type: 1a

1a- Vertical abutments with wingwalls

$1 \mathrm{~b}$ - Vertical abutments without wingwalls

2- Vertical abutments and wingwalls, sloping embankment Wingwalls perpendicular to abut. face

3- Spill through abutments

4- Sloping embankment, vertical wingwalls and abutments

Wingwall angle less than $90^{\circ}$.
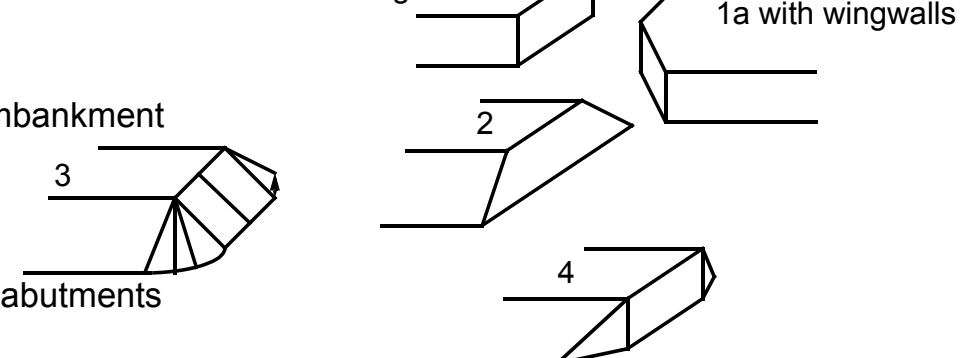

19. Bridge Deck Comments (surface cover variations, measured bridge and span lengths, bridge type variations, approach overflow width, etc.)

4. LBUS: road is within the forested area.

7. Measured bridge length: 31, span: 30, and width: 24 feet.

8. LB: is even with the bridge elevation for $30 \mathrm{ft}$. then rises.

18. The bridge is type 4 above end of wingwall elevation.

Although the computed opening skew to the roadway was 40 degrees, the abutment lengths were different. Therefore, the skew angle is closer to 45 degrees than the angle computed.

\section{Upstream Channel Assessment}

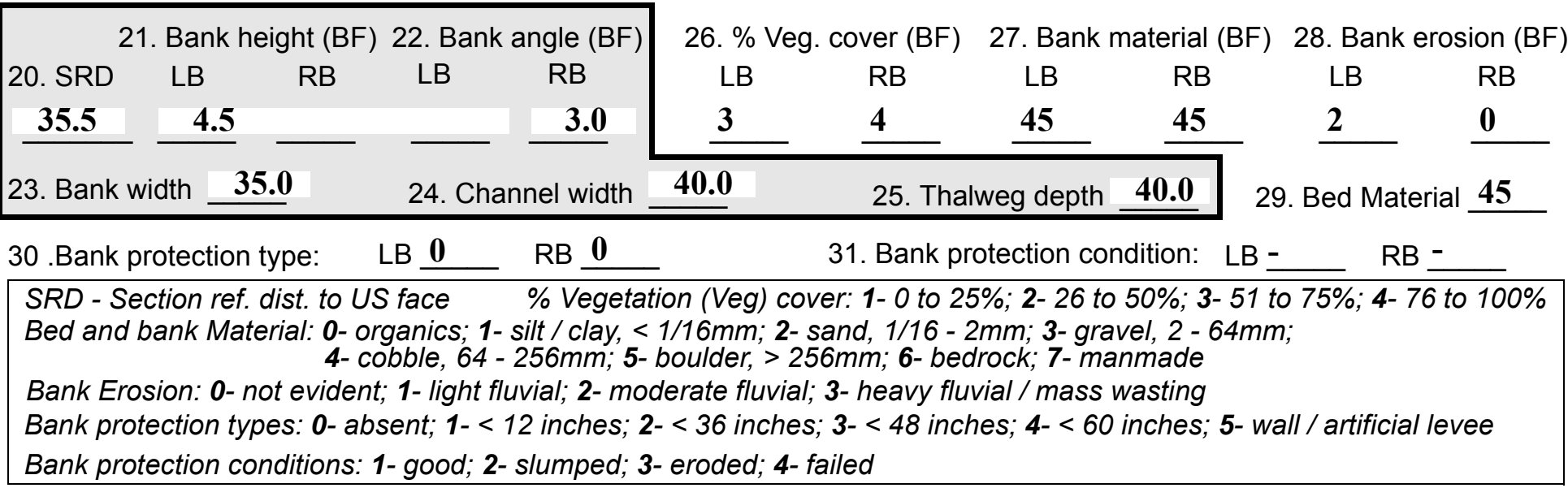

32. Comments (bank material variation, minor inflows, protection extent, etc.):

30. Both the left and right bank have natural protection consisting of cobble and boulder; left bank is exposed and the right bank is covered by some soil. 
36. Point bar extent: 172 feet $\underline{\text { US }}$ (US, UB) to 0 feet $\underline{\mathbf{U S}}$ (US, UB, DS) positioned $\underline{\mathbf{3 0}} \%$ LB to $100 \% \mathrm{RB}$

37. Material: 4

38. Point or side bar comments (Circle Point or Side; Note additional bars, material variation, status, etc.):

Flow comes around the bend upstream of $200 \mathrm{ft}$. towards the left bank causing erosion, and depositing the point bar on the right bank.

39. Is a cut-bank present? $\mathbf{Y}$ ( $Y$ or if $N$ type ctrl-n $c b)$

40. Where? LB (LB or RB)

41. Mid-bank distance: 110

42. Cut bank extent: 165 feet $\underline{\mathbf{U S}}$ (US, UB) to $\underline{\mathbf{6 0}}$

feet $\underline{\mathbf{U S}}$ (US, UB, DS)

43. Bank damage: 1

(1- eroded and/or creep; 2- slip failure; 3- block failure)

44. Cut bank comments (eg. additional cut banks, protection condition, etc.):

Slight cut bank on the right bank about 60 to $5 \mathrm{ft}$. upstream. Possibly due to constriction of the channel by road protection along the left bank just upstream of the bridge.

\section{Is channel scour present? $\mathbf{N}$ ( $Y$ or if $N$ type ctrl-n cs)}

47. Scour dimensions: Length Width -

Depth : -

46. Mid-scour distance: -

48. Scour comments (eg. additional scour areas, local scouring process, etc.):

\section{NO CHANNEL SCOUR}

Some local scour DS of boulders.

49. Are there major confluences? $\mathbf{N}$

51. Confluence 1: Distance -

Confluence 2: Distance -

NO MAJOR CONFLUENCES
(Y or if $N$ type ctrl-n mc)

52. Enters on -

Enters on (LB or $R B)$ (LB or $R B)$
50. How many? -

53. Type(1- perennial; 2- ephemeral)

Type (1-perennial; 2- ephemeral)

\section{Under Bridge Channel Assessment}

55. Channel restraint (BF)? LB 2

\begin{tabular}{|ccccc}
\hline \multicolumn{2}{|c}{ 56. Height (BF) } & \multicolumn{3}{c}{57 Angle (BF) } \\
LB & RB & LB & RB \\
$\mathbf{3 2 . 0}$ & & & $\mathbf{1 . 0}$ & \\
\hline
\end{tabular}
(1- natural bank; 2- abutment; 3- artificial levee)

58. Bank width (BF) -

59. Channel width (Amb) -

61. Material (BF)

LB RB

$\underline{2} \quad \underline{7}$
62. Erosion (BF)

LB RB

$7 \quad 0$
63. Bed Material $\mathbf{0}$

Bed and bank Material: 0- organics; 1- silt / clay, < 1/16mm; 2- sand, 1/16 - 2mm; 3- gravel, 2 - 64mm; 4- cobble, 64 - 256mm; 5- boulder, > 256mm; 6- bedrock; 7- manmade

Bank Erosion: 0- not evident; 1- light fluvial; 2- moderate fluvial; 3- heavy fluvial / mass wasting

64. Comments (bank material variation, minor inflows, protection extent, etc.):

54

There is a 3-step subfooting on the right abutment and a 2-step one on the left abutment. Both abutment walls are a combination of an old abutment extended upstream by newer abutments on both sides. The older wooden deck was left in place and new deck extends over the upstream side of the older deck. The new deck is curved while the old deck is straight. 
65. Debris and Ice Is there debris accumulation?

(Yor $N)$ 66. Where? $\mathbf{N}$

(1- Upstream; 2- At bridge; 3- Both)

67. Debris Potential ( 1-Low; 2- Moderate; 3- High)

68. Capture Efficiency 1 (1- Low; 2- Moderate; 3- High)

69. Is there evidence of ice build-up? 1 (Y or $N)$

Ice Blockage Potential $\mathbf{N}$

(1-Low; 2-Moderate; 3- High)

70. Debris and Ice Comments:

1

67. While there was no debris accumulation near the bridge, the upstream reach is laterally stable with a few cut banks, and may contribute debris.

68. Although the channel gradient is steep, the narrow bridge opening and the point bar upstream may result in debris capture near this site.

\begin{tabular}{|l|c|c|c|c|c|c|c|c|}
\hline Abutments & $\begin{array}{c}\text { 71. Attack } \\
\angle \mathrm{BF})\end{array}$ & $\begin{array}{c}\text { 72. Slope } \\
(\mathrm{Qmax})\end{array}$ & $\begin{array}{l}\text { 73. Toe } \\
\text { loc. (BF) }\end{array}$ & $\begin{array}{c}\text { 74. Scour } \\
\text { Condition }\end{array}$ & $\begin{array}{c}\text { 75. Scour } \\
\text { depth }\end{array}$ & $\begin{array}{c}\text { 76. Exposure } \\
\text { depth }\end{array}$ & 77. Material & 78. Length \\
\hline LABUT & & - & $\mathbf{9 0}$ & $\mathbf{2}$ & $\mathbf{2}$ & $\mathbf{0}$ & $\mathbf{3 . 5}$ & $\mathbf{9 0 . 0}$ \\
\hline RABUT & $\mathbf{1}$ & $\mathbf{5}$ & $\mathbf{9 0}$ & & & $\mathbf{2}$ & $\mathbf{3}$ & $\mathbf{2 1 . 0}$ \\
\hline
\end{tabular}

Pushed: $L B$ or RB

Toe Location (Loc.): 0- even, 1- set back, 2- protrudes

Scour cond.: 0- not evident; 1- evident (comment); 2- footing exposed; 3-undermined footing; 4- piling exposed; 5- settled; 6- failed

Materials: 1- Concrete; 2- Stone masonry or drywall; 3- steel or metal; 4- wood

79. Abutment comments (eg. undermined penetration, unusual scour processes, debris, etc.):

1.5

3.5

1

75. The streambed along the right abutment is 0.5 feet below the bottom of the 3 -step subfooting and the hole penetrates up to 2 feet under the subfooting.

76. The left abutment is a two step footing and was formed over a large boulder midway under the bridge.

The right abutment is a three step footing.

80. Wingwalls:

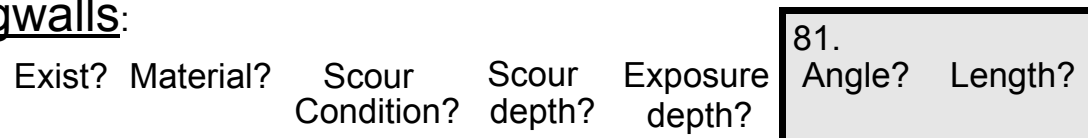

USLWW:

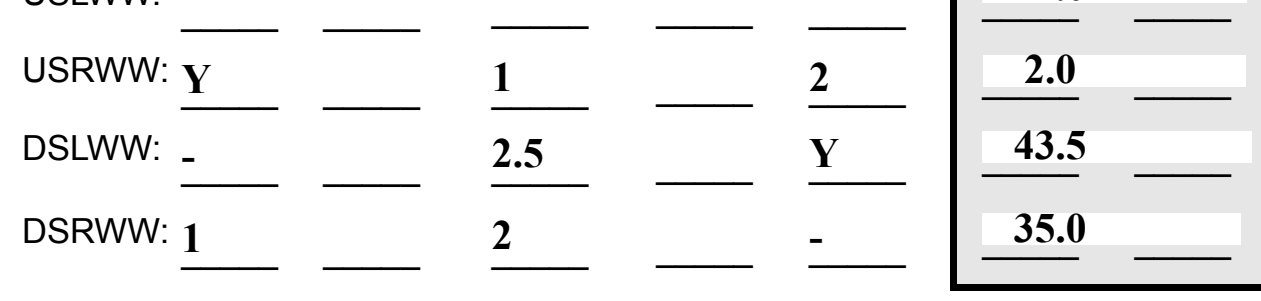

Wingwall materials: 1- Concrete; 2- Stone masonry or drywall; 3- steel or metal; 4- wood

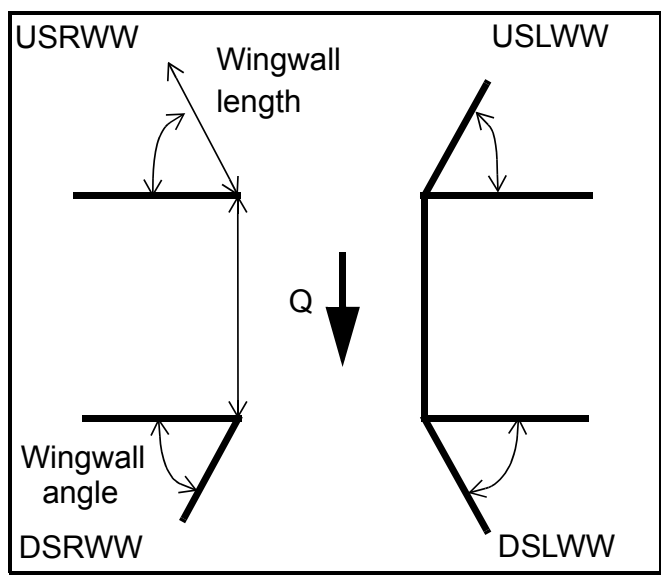

82. Bank / Bridge Protection:

\begin{tabular}{|l|l|l|l|l|l|l|l|c|}
\hline Location & USLWW & USRWW & LABUT & RABUT & LB & RB & DSLWW & DSRWW \\
\hline Type & $\mathbf{3}$ & $\mathbf{2}$ & $\mathbf{Y}$ & - & $\mathbf{1}$ & $\mathbf{1}$ & $\mathbf{1}$ & - \\
\hline Condition & $\mathbf{Y}$ & - & $\mathbf{1}$ & $\mathbf{3}$ & $\mathbf{1}$ & $\mathbf{1}$ & $\mathbf{2}$ & - \\
\hline Extent & $\mathbf{1}$ & $\mathbf{3}$ & $\mathbf{2}$ & $\mathbf{2}$ & $\mathbf{3}$ & $\mathbf{2}$ & $\mathbf{0}$ & - \\
\hline
\end{tabular}

Bank / Bridge protection types: 0- absent; 1- < 12 inches; 2- < 36 inches; 3- < 48 inches; 4- < 60 inches; 
83. Wingwall and protection comments (eg. undermined penetration, unusual scour processes, etc.):

-
-
-
-
-
2
3
1
0
-
-

\section{Piers:}

84. Are there piers? 82. (Y or if $N$ type ctrl-n pr)

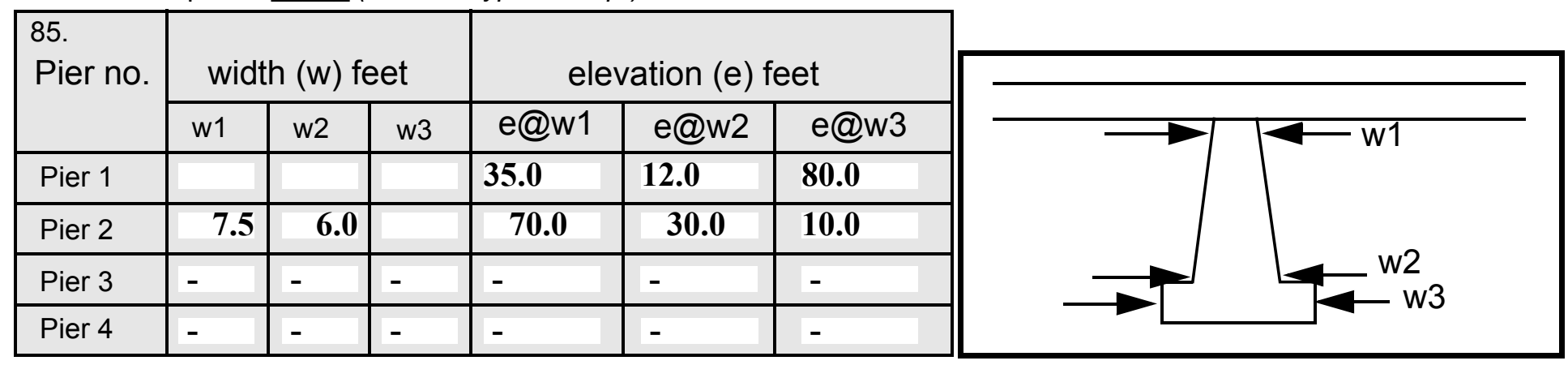

\begin{tabular}{|l|l|l|l|l|}
\hline Level 1 Pier Descr. & \multicolumn{1}{|c|}{1} & \multicolumn{1}{|c|}{2} & \multicolumn{1}{|c|}{3} & \multicolumn{1}{|c|}{4} \\
\hline 86. Location (BF) & The & s on & wing & the \\
\hline 87. Type & $3-$ & the & wall. & wing \\
\hline 88. Material & step & upst & Larg & wall. \\
\hline 89. Shape & right & ream & e & The \\
\hline 90. Inclined? & abut & right & boul- & abut \\
\hline 91. Attack $\angle$ (BF) & ment & wing & ders & ment \\
\hline 92. Pushed & foot- & wall & are & foot- \\
\hline 93. Length (feet) & - & - & - & - \\
\hline 94. \# of piles & ing & to & in & ing \\
\hline 95. Cross-members & expo & the & place & expo \\
\hline 96. Scour Condition & sure & end & to & sure \\
\hline 97. Scour depth & con- & of & pro- & also \\
\hline 98. Exposure depth & tinue & the & tect & con- \\
\hline
\end{tabular}

LFP, LTB, LB, MCL, MCM, MCR, RB, RTB, RFP

1- Solid pier, 2-column, 3- bent

1-Wood; 2- concrete; 3- metal; 4- stone

1- Round; 2- Square; 3- Pointed

Y-yes; $N$ - no

$L B$ or $R B$

0- none; 1- laterals; 2- diagonals; 3- both

0- not evident; 1- evident (comment);

2- footing exposed; 3- piling exposed;

4- undermined footing; 5- settled; 6- failed 
99. Pier comments (eg. undermined penetration, protection and protection extent, unusual scour processes, etc.): tinues on the downstream left and right wingwalls.

$\mathbf{N}$

100.

\section{E. Downstream Channel Assessment}

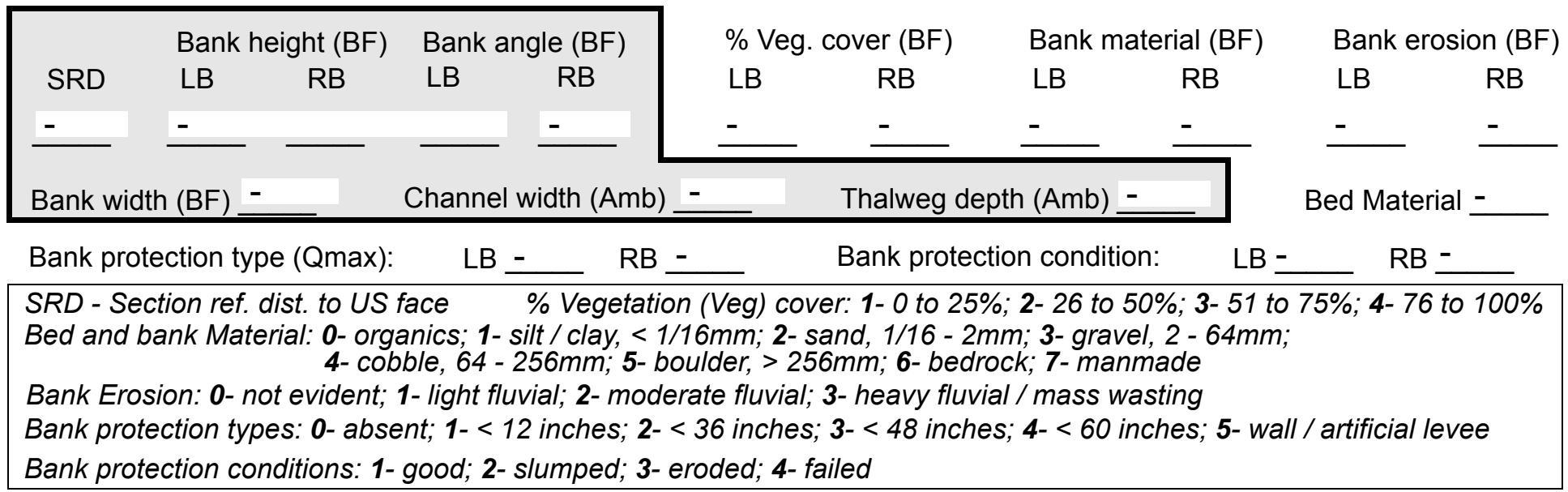

Comments (eg. bank material variation, minor inflows, protection extent, etc.):

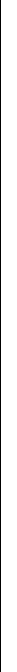

\section{Is a drop structure present? __ ( $Y$ or $N$, if $N$ type ctrl-n $d s) \quad$ 102. Distance: ___ feet}

103. Drop: __ feet 104. Structure material: ___ (1- steel sheet pile; 2- wood pile; 3- concrete; 4- other)

105. Drop structure comments (eg. downstream scour depth): 
106. Point/Side bar present? (Y or $N$. if $N$ type ctrl-n pb)Mid-bar distance:

Mid-bar width: -

Point bar extent: feet -

(US, UB, DS) to feet (US, UB, DS) positioned $\%$ LB to $\% \mathrm{RB}$ Material:

Point or side bar comments (Circle Point or Side; note additional bars, material variation, status, etc.):

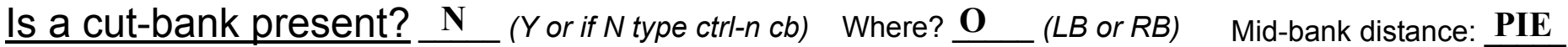
Cut bank extent: $\underline{\mathbf{R S}}$ feet __ (US, UB, DS) to feet (US, UB, DS)

Bank damage: (1- eroded and/or creep; 2- slip failure; 3- block failure)

Cut bank comments (eg. additional cut banks, protection condition, etc.):

Is channel scour present? Scour dimensions: Length $\underline{4}$ Width 54 ( $Y$ or if $N$ type ctrl-n cs)

Mid-scour distance: $\underline{4}$

Scour comments (eg. additional scour areas, local scouring process, etc.): 54

0

0

Are there major confluences? Confluence 1: Distance bank Confluence 2: Distance boul( $Y$ or if $N$ type ctrl-n $m c)$ Positioned $\underline{\mathbf{2}}$ \%LB to $\underline{\mathbf{0}}$ \%RB Confluence comments (eg. confluence name):

native material. The left bank erosion has exposed mostly boulders except at mid-cut bank where sand is evident. (170 to $200 \mathrm{ft}$. downstream)

\section{F. Geomorphic Channel Assessment}

107. Stage of reach evolution
How many? Both

Type have (1- perennial; 2- ephemeral)

Type size (1-perennial; 2- ephemeral) Enters on $\underline{\text { der }}(L B$ or $R B)$

1- Constructed

2- Stable

3- Aggraded

4- Degraded

5- Laterally unstable

6- Vertically and laterally unstable 
108. Evolution comments (Channel evolution not considering bridge effects; See HEC-20, Figure 1 for geomorphic descriptors): 


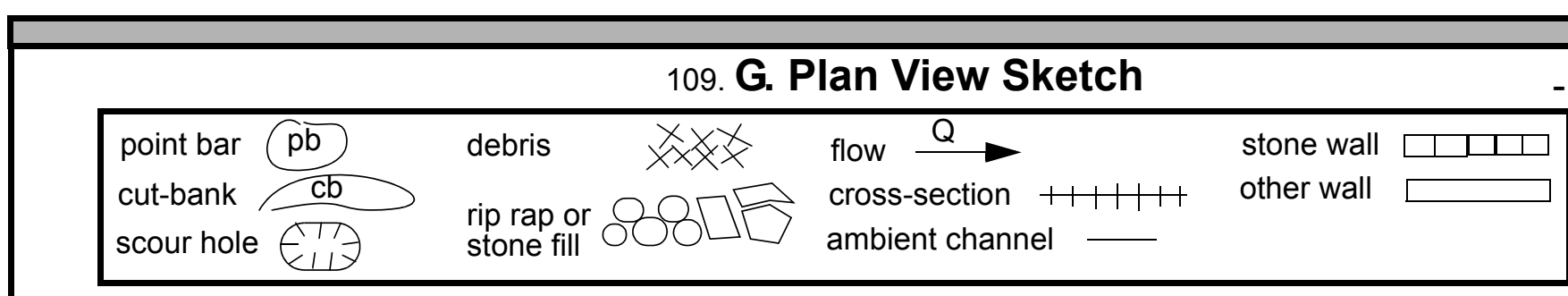


APPENDIX F:

SCOUR COMPUTATIONS 
SCOUR COMPUTATIONS

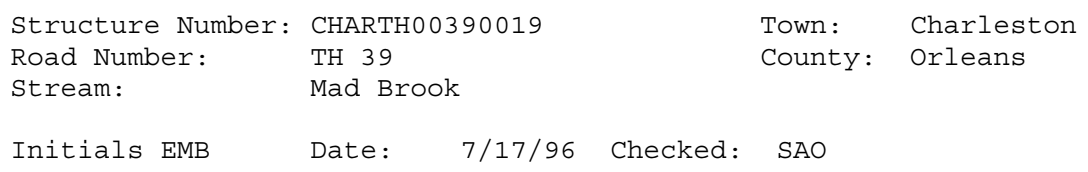

$0.63 \quad 4.59 \quad \mathrm{ERR}$ 
Clear water Contraction Scour in MAIN CHANNEL

\begin{tabular}{|c|c|c|c|}
\hline \multicolumn{4}{|c|}{$\begin{array}{l}\mathrm{y}^{2}=\left(\mathrm{Q} 2^{\wedge} 2 /\left(131 * \mathrm{Dm}^{\wedge}(2 / 3) * \mathrm{~W} 2^{\wedge} 2\right)\right)^{\wedge}(3 / 7) \quad \text { Converte } \\
\mathrm{ys}=\mathrm{y} 2-\mathrm{Y} \text { bridge } \\
(\mathrm{Ri} \text { chardson and others, } 1995, \mathrm{p} .32, \mathrm{eq} \cdot 20,20 \mathrm{a})\end{array}$} \\
\hline Approach section & Q100 & Q500 & Qother \\
\hline Main channel Area, ft2 & 301 & 394 & 0 \\
\hline Main channel width, ft & 45 & 52 & 0 \\
\hline y1, main channel depth, ft & 6.69 & 7.58 & ERR \\
\hline \multicolumn{4}{|l|}{ Bridge section } \\
\hline (Q) total discharge, cfs & 1300 & 1780 & 0 \\
\hline (Q) discharge thru bridge, cfs & 1300 & 1780 & \\
\hline Main channel conveyance & 11171 & 11171 & \\
\hline Total conveyance & 11171 & 11171 & \\
\hline Q2, bridge MC discharge, cfs & 1300 & 1780 & ERR \\
\hline Main channel area, ft2 & 180 & 180 & 0 \\
\hline Main channel width (skewed), ft & 20.2 & 20.2 & 0.0 \\
\hline Cum. width of piers in MC, ft & 0.0 & 0.0 & 0.0 \\
\hline w, adjusted width, ft & 20.2 & 20.2 & 0 \\
\hline y_bridge (avg. depth at br.), ft & 8.91 & 8.91 & ERR \\
\hline Dm, median $(1.25 * \mathrm{D} 50)$, ft & 0.55375 & 0.55375 & 0 \\
\hline $\mathrm{y}^{2}$, depth in contraction, ft & 5.20 & 6.81 & ERR \\
\hline ys, scour depth (y2-ybridge), ft & -3.71 & -2.10 & $\mathrm{~N} / \mathrm{A}$ \\
\hline Critical WSEL in bridge, ft & 493.15 & 494.29 & 0 \\
\hline Critical depth (approx), ft & 5.060891 & 6.200891 & $\mathrm{~N} / \mathrm{A}$ \\
\hline ys, depth of scour (critical), ft & 0.139109 & 0.609109 & $\mathrm{~N} / \mathrm{A}$ \\
\hline Full valley WSEL, ft & 493.54 & 494.54 & 0 \\
\hline Full valley depth (approx), ft & 5.450891 & 6.450891 & $\mathrm{~N} / \mathrm{A}$ \\
\hline ys, depth of scour (FULLV), ft & -0.25089 & 0.359109 & $\mathrm{~N} / \mathrm{A}$ \\
\hline \multicolumn{4}{|c|}{ Pressure Flow Scour (contraction scour for orifice flow condtions) } \\
\hline \multirow{2}{*}{\multicolumn{4}{|c|}{$\begin{array}{l}\mathrm{Hb}+\mathrm{Ys}=\mathrm{Cq} * \mathrm{qbr} / \mathrm{VC} \\
\text { Chang Equation }\end{array}$}} \\
\hline & & & \\
\hline & Q100 & Q500 & OtherQ \\
\hline Q thru bridge main chan, cfs & 1300 & 1780 & 0 \\
\hline Vc, critical velocity, ft/s & 11.7 & 12 & 0 \\
\hline Vc, critical velocity, m/s & 3.565986 & 3.657422 & 0 \\
\hline Main channel width (skewed), ft & 20.2 & 20.2 & 0 \\
\hline Cum. width of piers, ft & 0 & 0 & 0 \\
\hline w, adjusted width, ft & 20.2 & 20.2 & 0 \\
\hline qbr, unit discharge, $f t^{\wedge} 2 / \mathrm{s}$ & 64.35644 & 88.11881 & ERR \\
\hline qbr, unit discharge, $\mathrm{m}^{\wedge} 2 / \mathrm{s}$ & 5.978325 & 8.185707 & $\mathrm{~N} / \mathrm{A}$ \\
\hline Area of full opening, $\mathrm{ft}^{\wedge} 2$ & 180 & 180 & 0 \\
\hline $\mathrm{Hb}$, depth of full opening, ft & 8.910891 & 8.910891 & ERR \\
\hline $\mathrm{Hb}$, depth of full opening, $\mathrm{m}$ & 2.715907 & 2.715907 & $\mathrm{~N} / \mathrm{A}$ \\
\hline Fr, Froude number $\mathrm{MC}$ & 0.51 & 0.69 & 1 \\
\hline Cf, Fr correction factor $(<=1.0)$ & 1 & 1 & 1.5 \\
\hline Elevation of Low steel, ft & 497 & 497 & 0 \\
\hline Elevation of Bed, ft & 488.0891 & 488.0891 & $\mathrm{~N} / \mathrm{A}$ \\
\hline Elevation of approach WS, ft & 498.14 & 500.05 & 0 \\
\hline HF, bridge to approach, ft & 0.06 & 0.08 & 0 \\
\hline Elevation of WS immediately US, ft & 498.08 & 499.97 & 0 \\
\hline ya, depth immediately US, ft & 9.990891 & 11.88089 & $\mathrm{~N} / \mathrm{A}$ \\
\hline ya, depth immediately US, m & 3.10469 & 3.692011 & $\mathrm{~N} / \mathrm{A}$ \\
\hline Mean elev. of deck, ft & 501.45 & 501.45 & 0 \\
\hline w, depth of overflow, ft $(>=0)$ & 0 & 0 & 0 \\
\hline Cc, vert contrac correction $(<=1.0)$ & 0.972182 & 0.927847 & ERR \\
\hline
\end{tabular}


Abutment Scour

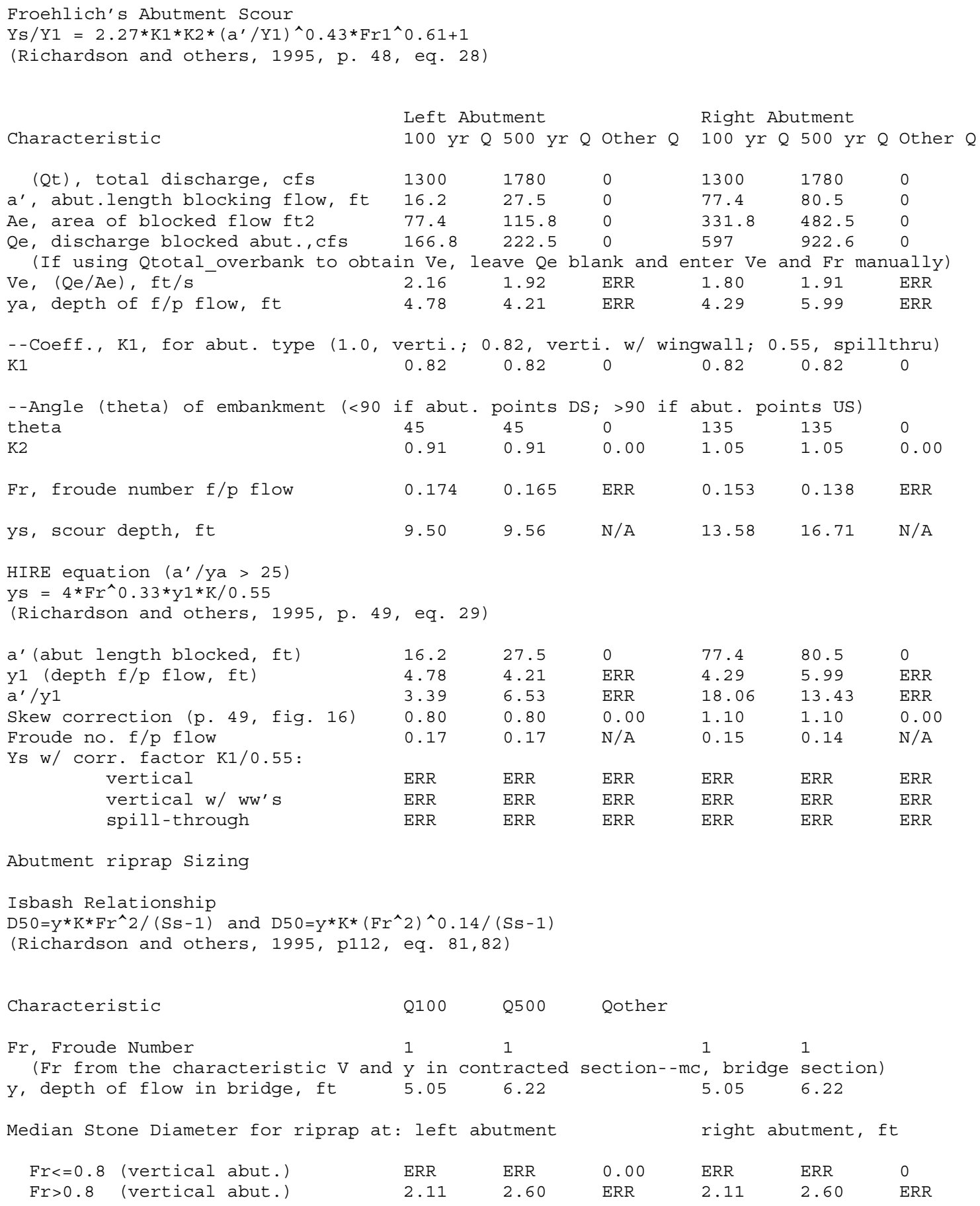

